\title{
Frailty, nutrition-related parameters, and mortality across the adult age spectrum
}

\author{
Kulapong Jayanama ${ }^{1,2}$, Olga Theou ${ }^{2,3}$, Joanna M Blodgett ${ }^{4}$, Leah Cahill ${ }^{2,5}$ and Kenneth Rockwood ${ }^{3,6^{*}}$
}

\begin{abstract}
Background: Nutritional status and individual nutrients have been associated with frailty in older adults. The extent to which these associations hold in younger people, by type of malnutrition or grades of frailty, is unclear. Our objectives were to (1) evaluate the relationship between individual nutrition-related parameters and frailty, (2) investigate the association between individual nutrition-related parameters and mortality across frailty levels, and (3) examine whether combining nutrition-related parameters in an index predicts mortality risk across frailty levels.

Methods: This observational study assembled 9030 participants aged $\geq 20$ years from the 2003-2006 cohorts of the National Health and Nutrition Examination Survey who had complete frailty data. A 36-item frailty index (FI) was constructed excluding items related to nutritional status. We examined 62 nutrition-related parameters with established cut points: 34 nutrient intake items, 5 anthropometric measurements, and 23 relevant blood tests. The 41 nutritionrelated parameters which were associated with frailty were combined into a nutrition index (NI). All-cause mortality data until 2011 were identified from death certificates.
\end{abstract}

Results: All 5 anthropometric measurements, 21/23 blood tests, and 19/34 nutrient intake items were significantly related to frailty. Although most nutrition-related parameters were directly related to frailty, high alcohol consumption and high levels of serum alpha-carotene, beta-carotene, beta-cryptoxanthin, total cholesterol, and LDL-c were associated with lower frailty scores. Only low vitamin D was associated with increased mortality risk across all frailty levels. Seventeen nutritionrelated parameters were associated with mortality in the 0.1-0.2 Fl group, 11 in the 0.2-0.3 group, and 16 in the $>0.3$ group. Overall, 393 (5.8\%) of the participants had an NI score less than 0.1 (abnormality in $\leq 4$ of the 41 parameters examined). Higher levels of $\mathrm{NI}$ were associated with higher mortality risk after adjusting for frailty and other covariates (HR per 0.1: 1.19 [95\%Cl 1.133-1.257]).

Conclusions: Most nutrition-related parameters were correlated to frailty, but only low vitamin D was associated with higher risk for mortality across levels of frailty. As has been observed with other age-related phenomena, even though many nutrition-related parameters were not significantly associated with mortality individually, when combined in an index, they strongly predicted mortality risk.

Keywords: Nutrition, Dietary intake, Frailty, Frailty index, Mortality, NHANES

\section{Background}

Reflecting the increasing life expectancy of the global population [1], the number of adults aged 65 years or older is predicted to double by 2050 [2]. In parallel, the prevalence of age-related health deficits including

\footnotetext{
* Correspondence: Kenneth.rockwood@nshealth.ca

${ }^{3}$ Centre for Health Care of the Elderly, QEll Health Sciences Centre, Nova Scotia Health Authority, Halifax, Nova Scotia, Canada

${ }^{6}$ Division of Geriatric Medicine, Department of Medicine, Dalhousie

University, Camp Hill Veterans' Memorial Bldg., 5955 Veterans' Memorial Lane, Halifax, Nova Scotia B3H 2E1, Canada

Full list of author information is available at the end of the article
}

cardiovascular, metabolic, cognitive, and musculoskeletal diseases is growing [3-6]. Frailty is a multiply determined, age-related state of vulnerability to adverse health outcomes compared with others of the same age $[7,8]$. It is associated with a range of adverse outcomes, including morbidity, mortality, and increased healthcare costs $[9,10]$. Frailty can be observed at all adult ages and is closely tied to ageing, suggesting that the prevalence of frailty is likely to increase as populations age [11]. Even so, two European cohorts have observed only very modest increases with age in the 
mean frailty, despite varying estimates in the extent of its lethality, especially in people with milder degrees of frailty $[12,13]$.

Against this background, two considerations motivate a more comprehensive understanding of the relationship between nutrition and frailty. First, the two are linked. The prevalence of malnourished individuals can be high in ageing populations, especially in rehabilitation, hospital, and nursing home settings $[14,15]$. Malnutrition, which is affected by inadequate, excessive, or imbalance of energy or nutrient consumption, is associated with physical and cognitive impairment, poor quality of life, morbidity, and mortality in older individuals [16-20]. Malnutrition is also associated with higher levels of frailty $[8,21]$.

Second, optimal nutrition management can improve frailty $[22,23]$ and some nutrient intakes or supplements, for example, fish oil and antioxidants, are associated with reduced frailty levels [24-27]. Nutrition management therefore appears to make poor nutrition a modifiable risk factor in relation to frailty. Importantly too, nutrition management appears to work well, in both hospital and community settings, as part of multidimensional interventions that also include exercise, pharmacological treatment, and social support [28-31].

Despite these promising insights, the evidence about the relationship of nutrition-related parameters with frailty, and whether these associations hold in younger people and by type of malnutrition, is limited and inconsistent [32-35]. Further, the multiplicity of claims about which nutritional factors might be most important is a pragmatic obstacle to uptake [8,36-38]. This obscures how the relationship might arise, and where new interventions might best be targeted. In other contexts in which the impact of age-related adverse outcomes varies by which items are studied, it has been useful to study deficits in the aggregate [39], something which has been variably applied in nutrition studies [40]. To help improve the understanding of the relationship between frailty and nutrition, this study aims (1) to evaluate the relationship between individual nutrition-related parameters and frailty, (2) to investigate the effect of these parameters on mortality risk across levels of frailty, and (3) to examine whether combining nutrition-related parameters in an index predicts mortality risk across frailty levels.

\section{Methods}

\section{Study population and design}

This observational study used data from 10,020 individuals aged 20 years or more from the 2003-2004 and 2005-2006 cohorts of the National Health and Nutrition Examination Survey (NHANES). NHANES is a series of publicly available, cross-sectional surveys focusing on the health and nutrition of non-institutionalized US residents [41, 42]. For the purpose of this study, 990 individuals with missing FI scores were excluded. The final sample included 9030 participants. Mortality status was identified from the death certificate records from the National Death Index in December 31, 2011, and survival time was counted from the date of the clinical examination to the death event.

Each participant signed written informed consent provided to participate. The NHANES protocol was approved by the institutional review board of the Centers for Disease Control and Prevention (CDC). As a matter of policy, our local Research Ethics Committee does not review secondary analyses of duly approved, publicly available data.

\section{Nutrition-related data}

Of 84 nutrition-related parameters included in NHANES, 62 items had established cut points. Among them, 34 energy and nutrient intake items were estimated from dietary information recalled during the $24-\mathrm{h}$ period prior to the interview. Five anthropometric measurements and 23 blood tests related to nutrition were collected with standard techniques. The normal range of each parameter is shown in Table 5 in Appendix. These cut points were taken from a standard textbook, the Dietary Reference Intake (DRIs), published guidelines, and previous studies $[11,43-55]$.

\section{Frailty index}

The FI used in this study included 36 items and was modified from a previously validated FI in NHANES $[11,56]$ (Table 6 in Appendix). We excluded from the FI all items related to dietary intake or nutritional status (i.e. difficulty using fork and knife, difficulty preparing meals, glycohaemoglobin, triglyceride, creatinine, haemoglobin, mean corpuscular volume, total cholesterol, glucose, and sodium). The FI score, the number of deficits present divided by the total deficits considered, ranges between 0 and 1 , and a higher score is associated with higher frailty. For stratification purposes, we grouped participants into 4 FI groups: $\mathrm{FI} \leq 0.1$ (fit), $0.1<\mathrm{FI} \leq 0.2$ (vulnerable), $0.2<\mathrm{FI} \leq 0.3$ (mildly frail), and FI $>0.3$ (moderately/severely frail) [56].

\section{Nutrition index}

A nutrition index (NI) was constructed following the deficit accumulation approach [57] by combining the 41 nutrition-related parameters that were related with higher frailty: counting the number of nutritional deficits in an individual and dividing by the total deficits considered. Low-density lipoprotein cholesterol (LDL- 
c) and subscapular skinfold were excluded from the NI due to high number of missing data: $53.9 \%$ for LDL-c and $23.8 \%$ for subscapular skinfold. Each nutritional parameter was scored " 1 " if the value fell outside the normal range and "0" otherwise. Abnormal values that were found to be protective for frailty (associated with lower levels of frailty) were also scored as 0 (Table 5 in Appendix). An NI score was only calculated for individuals with $>80 \%$ of the variables complete. The NI score ranges between 0 and 1; an NI score of 0 represents full nutritional health, while a score of 1 represents complete nutritional deficits. In the analysis, we used both the continuous NI score and a categorical variable: $\mathrm{NI} \leq 0.2,0.2<\mathrm{NI} \leq 0.3,0.3<\mathrm{NI} \leq 0.4,0.4<\mathrm{NI} \leq 0.5$, and $\mathrm{NI}>0.5$.

\section{Statistical analysis}

Demographic characteristics of the subjects are presented as mean \pm standard deviation (SD) for continuous variables and as frequency (\%) for binary or categorical variables. All percentages and mean values were weighted using the sampling weights provided by NHANES. Multiple linear regression analysis was used to assess the associations between each nutrition-related parameter, NI and FI scores and is presented by $\beta$-coefficient with $95 \%$ confidence interval (CI). The mortality risk from each parameter across the FI group was analysed using Cox regression models, and the odds of mortality risk was presented using the hazard ratios and the associated 95\%CI. All regression models were adjusted for potential covariates including age, sex, race, energy intake, educational level, marital status, employment status, smoking, and study cohort. Models which included energy, energy per weight, dietary fiber per energy intakes, and NI as predictors were not adjusted for energy intake. Annual household income was not included as covariate due to missing data. Statistical significance was considered as a $p$ value $<0.05$, and all reported probability tests were two-sided. The statistical analysis was conducted using IBM SPSS Statistics for Windows, Version 24.0. Armonk, NY: IBM Corp.

\section{Results}

Of the 9030 included participants, 48\% were male; their weighted mean age was $46.6 \pm 16.9$ years. When we stratified the sample by frailty, 5119 (56.7\%), 2009 (22.2\%), $1014(11.2 \%)$, and $888(9.8 \%)$ had an FI score $<0.1,0.1-0.2,0.2-0.3$, and $>0.3$, respectively. The weighted mortality rate was $6.5 \%$ (940/9030). The demographic characteristics of the sample by frailty categories are presented in Table 1. In the frailer groups, the mean age and number of people with female gender, lower education, non-full-time work, and low income were significantly higher $(p<0.001)$ (Table 1).

Regarding objective 1 (to evaluate the relationship between individual nutrition-related parameters and frailty), many but not all nutrition-related parameters-especially those related to self-reported intakevaried in relation to the degree of frailty. The proportion of individuals who had abnormal dietary intakes differed significantly between FI groups in almost all variables, except high intake of saturated fat (\%), vitamin A, iron, zinc, copper, selenium, and caffeine, and low intake of vitamin A and vitamin C (Table 2). Related to anthropometric measurement, only the percentage of individuals who were underweight and had low subscapular skinfold thickness did not significantly differ between FI groups (Table 3). Similarly, the proportion of individuals who had abnormal blood tests differed significantly between FI groups in almost all variables, except low MCV, low levels of folate in red blood cell and plasma glucose, and high levels of haemoglobin, serum beta-carotene, serum lutein/zeaxanthin, and serum iron (Table 4).

Linear regression models, adjusted for the potential covariates, revealed statistically significant associations between frailty and the inappropriate intake of many nutrients (Table 7 in Appendix), the abnormal range of many anthropometric measures (Table 8 in Appendix), and the abnormality of many nutrition-related blood tests (Table 9 in Appendix). To summarize, frailty was associated with 19 nutrient intakes (Fig. 1a). Low energy intake per weight showed the highest positive correlation with frailty $(\beta$-coefficient 0.018 , 95\%CI $0.014-0.021)$ followed by low protein per weight intake $(0.016,0.011-0.020)$, whereas high consumption of energy per weight, sodium, and alcohol were significantly associated with lower FI score. With regard to anthropometric measurements, only being overweight was significantly associated with lower frailty. Obesity, high waist circumference, triceps and subscapular skinfold thickness, and body weight change (loss and gain more than $10 \%$ ) were significantly associated with higher FI score (Fig. 1b). Almost all blood tests (21/23) were significantly correlated with frailty. The highest association was found in low serum vitamin A $(\beta$-coefficient 0.085 , 95\%CI 0.030-0.139). High serum levels of alpha-carotene, beta-carotene, beta-cryptoxanthin, lutein/zeaxanthin, lycopene, total cholesterol, and LDL-c were inversely associated with FI score (Fig. 1c).

Results related to the relationship of the nutrition-related parameters with mortality risk (objective 2) are presented in Fig. 2 and Tables 10, 11, and 12 in Appendix. To summarize, only one abnormal blood test (low vitamin D which was associated with mortality risk at all grades of frailty) showed a relationship with mortality in people with 
Table 1 Demographic characteristics of participants by frailty level

\begin{tabular}{|c|c|c|c|c|}
\hline \multirow[t]{2}{*}{ Characteristics } & \multicolumn{4}{|c|}{ Frailty index score } \\
\hline & $\begin{array}{l}\leq 0.1 \\
N=5119\end{array}$ & $\begin{array}{l}>0.1 \text { to } 0.2 \\
N=2009\end{array}$ & $\begin{array}{l}>0.2 \text { to } 0.3 \\
N=1014\end{array}$ & $\begin{array}{l}>0.3 \\
N=888\end{array}$ \\
\hline Age (year), mean $\pm S D$ & $39.7 \pm 13.2$ & $54.8 \pm 15.8$ & $62.8 \pm 14.5$ & $65.3 \pm 14.4$ \\
\hline Sex, female, $N(\%)$ & $2540(48.3)$ & $1114(58.7)$ & $529(56.2)$ & $504(60.9)$ \\
\hline \multicolumn{5}{|l|}{ Race, N (\%) } \\
\hline Non-Hispanic White & $2478(70.4)$ & $1112(75.6)$ & $611(79.9)$ & $493(73.1)$ \\
\hline Non-Hispanic Black & $1057(10.6)$ & $409(10.8)$ & $196(10.7)$ & $212(15.1)$ \\
\hline Hispanic & $1356(13.5)$ & $416(8.8)$ & $179(5.5)$ & $144(5.8)$ \\
\hline Other & $228(5.5)$ & $72(4.7)$ & $28(4.0)$ & $39(5.9)$ \\
\hline \multicolumn{5}{|l|}{ Education, $N(\%)$} \\
\hline Less than high school & $1193(14.3)$ & $614(19.5)$ & $384(27.6)$ & $386(33.1)$ \\
\hline High school & $1195(24.4)$ & $513(27.4)$ & $277(30.3)$ & $211(29.3)$ \\
\hline $\begin{array}{l}\text { Some college/associated } \\
\text { education }\end{array}$ & $1560(32.7)$ & $528(31.1)$ & $226(26.4)$ & $204(27.6)$ \\
\hline College graduate or more & $1167(28.6)$ & $352(22.0)$ & $127(15.7)$ & $80(10.0)$ \\
\hline \multicolumn{5}{|l|}{$\begin{array}{l}\text { Annual household Income } \\
\text { (USD), N (\%) }\end{array}$} \\
\hline $0-19,999$ & $802(11.1)$ & $478(18.2)$ & $335(27.3)$ & $385(39.2)$ \\
\hline $20,000-44,999$ & $1533(27.0)$ & $686(33.0)$ & $354(38.3)$ & 266 (34.6) \\
\hline $45,000-74,999$ & $1149(26.2)$ & $391(25.6)$ & $143(21.2)$ & $120(18.4)$ \\
\hline$\geq 75,000$ & $1336(35.7)$ & $335(23.3)$ & $107(13.2)$ & $55(7.8)$ \\
\hline \multicolumn{5}{|l|}{ Marital status, N (\%) } \\
\hline Married & $3376(67.8)$ & $1245(65.4)$ & $569(59.9)$ & $402(50.0)$ \\
\hline Widowed & $129(1.9)$ & $280(10.7)$ & $225(16.8)$ & $260(24.2)$ \\
\hline Divorced or separated & $500(10.2)$ & $294(14.8)$ & $154(16.7)$ & $164(18.7)$ \\
\hline Never married & $1110(20.2)$ & $190(9.1)$ & $65(6.6)$ & $61(7.2)$ \\
\hline Full-time working, $N(\%)$ & $3819(80.7)$ & $882(53.4)$ & $214(28.1)$ & $72(11.7)$ \\
\hline \multicolumn{5}{|l|}{ Smoking status, N (\%) } \\
\hline Never & $2864(53.5)$ & $988(47.4)$ & $411(40.1)$ & $377(41.2)$ \\
\hline Former & $1021(20.5)$ & $600(29.7)$ & $414(38.1)$ & $346(37.7)$ \\
\hline Current & $1234(26.0)$ & $421(22.9)$ & 189 (21.8) & $165(21.1)$ \\
\hline
\end{tabular}

The percentages and mean values are weighted

USD United States Dollar

$\mathrm{FI} \leq 0.1$; four nutrient intakes, three anthropometric measurements, and ten blood tests in people with 0.1-0.2 FI; one nutrient intake, four anthropometric measurements, and six blood tests in people with 0.2-0.3 FI; and three nutrient intakes, three anthropometric measurements, and ten blood tests in people with $\mathrm{FI}>0.3$. Participants with $\mathrm{FI}>0.1$ who reported that they lost more than $10 \%$ of their weight in the past year had higher mortality risk. Being underweight and low serum creatinine levels were associated with higher mortality risk in individuals with $\mathrm{FI}>0.2$. Being overweight, having high waist circumference, and caffeine consumption were significantly associated with lower mortality risk in individuals with $\mathrm{FI}>0.3$.
Regarding objective 3 (to examine whether combining nutrition-related parameters in an index predicts mortality risk across frailty levels), we could not calculate the NI score for 500 individuals due to missing $>20 \%$ of the nutritional parameters included in the index (total included $n=8530)$. Overall, $393(5.8 \%)$ of the participants had an NI score less than 0.1 (abnormality in $\leq 4$ of the 41 parameters examined). This proportion decreased with higher frailty, from $7.4 \%$ among those with $\mathrm{FI}<0.1$ to $0.7 \%$ among those with FI $>0.3$ (Fig. 3 and Table 13 in Appendix). The weighted mean NI score was $0.29 \pm 0.13$ (range 0.00-0.79) and was significantly higher for those people with higher frailty levels: $0.26 \pm 0.12$ for $\mathrm{FI} \leq 1,0.31 \pm 0.13$ for $0.1-0.2$ FI, $0.35 \pm 0.13$ for $0.2-0.3 \mathrm{FI}$, and $0.40 \pm 0.14$ for $\mathrm{FI}>0.3$. 
Table 2 Number of participants with abnormal range of daily nutrient intakes by frailty level

\begin{tabular}{|c|c|c|c|c|c|}
\hline \multirow[t]{2}{*}{ Nutrients, $N(\%)^{*}$} & & \multicolumn{4}{|c|}{ Frailty index score } \\
\hline & & $\begin{array}{l}\leq 0.1 \\
N=5119\end{array}$ & $\begin{array}{l}>0.1 \text { to } 0.2 \\
N=2009\end{array}$ & $\begin{array}{l}>0.2 \text { to } 0.3 \\
N=1014\end{array}$ & $\begin{array}{l}>0.3 \\
N=888\end{array}$ \\
\hline Energy $(N=8614)$ & Low & $2218(44.4)$ & $1157(55.3)$ & $297(63.8)$ & $203(71.7)$ \\
\hline \multirow[t]{2}{*}{ Energy per weight $(N=8510)$} & Low & 1950 (39.8) & $1051(54.1)$ & $605(60.9)$ & $566(69.7)$ \\
\hline & High & 1479 (30.8) & $307(17.4)$ & $108(13.9)$ & $64(7.9)$ \\
\hline Protein $(N=8614)$ & Low & $821(15.6)$ & $450(20.9)$ & $297(27.5)$ & $303(33.5)$ \\
\hline Protein per weight $(N=8510)$ & Low & $1524(29.0)$ & $955(46.8)$ & $563(55.0)$ & $524(63.6)$ \\
\hline Carbohydrate $(N=8614)$ & Low & $1068(22.8)$ & $608(31.1)$ & $357(35.5)$ & $360(41.2)$ \\
\hline Simple sugar $(N=8614)$ & High & $4633(94.6)$ & $1778(92.9)$ & $896(93.1)$ & $758(91.7)$ \\
\hline Dietary fiber per energy $(N=8613)$ & Low & $4590(94.6)$ & $1713(91.0)$ & $870(91.9)$ & $755(92.8)$ \\
\hline \multirow[t]{2}{*}{ Percentage of fat $(N=8614)$} & Low & $119(2.0)$ & $83(3.6)$ & $41(4.2)$ & $46(4.6)$ \\
\hline & High & $4413(91.1)$ & $1650(88.1)$ & $799(85.0)$ & $670(82.7)$ \\
\hline $\begin{array}{l}\text { Percentage of saturated fat } \\
(N=8613)\end{array}$ & High & $2827(59.6)$ & $1078(59.0)$ & $554(57.4)$ & $479(60.8)$ \\
\hline Cholesterol $(N=8614)$ & High & $1924(39.2)$ & $652(33.4)$ & $312(30.9)$ & $255(28.5)$ \\
\hline \multirow[t]{2}{*}{ Vitamin A, RAE $(N=8614)$} & Low & $3725(75.0)$ & $1502(76.8)$ & $745(76.1)$ & $647(76.7)$ \\
\hline & High & $31(0.7)$ & $5(0.1)$ & $11(1.0)$ & $4(0.5)$ \\
\hline \multirow[t]{2}{*}{ Vitamin $C(N=8614)$} & Low & $2903(62.2)$ & $1165(61.8)$ & $598(63.2)$ & $516(65.1)$ \\
\hline & High & $0(0.0)$ & $0(0.0)$ & $0(0.0)$ & $1(0.1)$ \\
\hline Vitamin $E(N=8614)$ & Low & $4548(92.4)$ & $1814(93.2)$ & $931(94.9)$ & $802(95.9)$ \\
\hline Vitamin K (N = 8614) & Low & $3754(74.4)$ & $1503(76.0)$ & $776(78.0)$ & $679(80.6)$ \\
\hline Thiamin $(N=8614)$ & Low & $1411(27.3)$ & $700(34.3)$ & $362(35.2)$ & $375(42.6)$ \\
\hline Riboflavin $(N=8614)$ & Low & $831(14.5)$ & $359(15.7)$ & $189(17.4)$ & 212 (23.6) \\
\hline \multirow[t]{2}{*}{ Niacin $(N=8614)$} & Low & $981(18.0)$ & $544(25.3)$ & $301(26.2)$ & $332(37.1)$ \\
\hline & High & $1020(23.0)$ & $223(13.1)$ & $95(13.0)$ & $65(8.7)$ \\
\hline Pyridoxine $(N=8614)$ & Low & $1596(32.2)$ & $898(43.7)$ & $507(47.9)$ & $470(54.0)$ \\
\hline \multirow[t]{2}{*}{ Folate $(N=8614)$} & Low & $2751(54.8)$ & $1236(63.3)$ & $658(64.6)$ & $606(71.3)$ \\
\hline & High & $138(3.2)$ & $38(2.1)$ & $19(2.7)$ & $10(1.3)$ \\
\hline Cobalamin $(N=8614)$ & Low & $1252(24.5)$ & $593(28.5)$ & $307(30.5)$ & $287(32.8)$ \\
\hline \multirow[t]{2}{*}{ Calcium $(N=8614)$} & Low & $3150(63.7)$ & $1457(73.4)$ & $787(78.4)$ & $698(81.0)$ \\
\hline & High & $125(2.8)$ & $30(1.8)$ & $9(1.2)$ & $4(0.8)$ \\
\hline \multirow[t]{2}{*}{ Phosphorous $(N=8614)$} & Low & $551(10.1)$ & $322(14.7)$ & $187(18.5)$ & $217(24.7)$ \\
\hline & High & $29(0.5)$ & $8(0.5)$ & $1(0.3)$ & $0(0.0)$ \\
\hline Magnesium ( $N=8614)$ & Low & $3656(74.2)$ & $1526(76.9)$ & $828(82.7)$ & $731(87.1)$ \\
\hline \multirow[t]{2}{*}{ Iron $(N=8614)$} & Low & $1750(34.7)$ & $579(30.7)$ & $223(23.3)$ & $228(29.0)$ \\
\hline & High & $65(1.4)$ & $21(1.1)$ & $7(1.0)$ & $5(0.7)$ \\
\hline \multirow[t]{2}{*}{$\operatorname{Zinc}(N=8614)$} & Low & $1863(36.3)$ & $898(42.8)$ & $531(49.7)$ & $468(52.5)$ \\
\hline & High & $56(1.2)$ & $14(0.8)$ & $8(1.0)$ & $3(0.3)$ \\
\hline \multirow[t]{2}{*}{ Copper $(N=8614)$} & Low & $1322(25.5)$ & $663(31.9)$ & $369(34.8)$ & $379(44.4)$ \\
\hline & High & $10(0.3)$ & $1(0.0)$ & $2(0.1)$ & $1(0.1)$ \\
\hline \multirow[t]{2}{*}{ Sodium $(N=8614)$} & Low & $359(6.2)$ & $183(8.0)$ & $81(7.5)$ & $117(12.4)$ \\
\hline & High & $3742(79.2)$ & $1219(65.8)$ & $599(64.5)$ & $435(54.2)$ \\
\hline Potassium $(N=8614)$ & Low & $4484(91.4)$ & $1799(92.4)$ & $935(95.6)$ & $810(96.7)$ \\
\hline \multirow[t]{2}{*}{ Selenium $(N=8614)$} & Low & $571(10.8)$ & $344(16.9)$ & $203(20.4)$ & $228(26.4)$ \\
\hline & High & $15(0.3)$ & $8(0.5)$ & $1(0.1)$ & $0(0.0)$ \\
\hline
\end{tabular}


Table 2 Number of participants with abnormal range of daily nutrient intakes by frailty level (Continued)

\begin{tabular}{|c|c|c|c|c|c|}
\hline \multirow[t]{2}{*}{ Nutrients, $N(\%)^{*}$} & & \multicolumn{4}{|c|}{ Frailty index score } \\
\hline & & $\begin{array}{l}\leq 0.1 \\
N=5119\end{array}$ & $\begin{array}{l}>0.1 \text { to } 0.2 \\
N=2009\end{array}$ & $\begin{array}{l}>0.2 \text { to } 0.3 \\
N=1014\end{array}$ & $\begin{array}{l}>0.3 \\
N=888\end{array}$ \\
\hline Caffeine $(N=8614)$ & High & $489(14.2)$ & $191(13.5)$ & $82(12.3)$ & $80(11.4)$ \\
\hline Alcohol $(N=8614)$ & High & $885(21.7)$ & $270(16.8)$ & $111(12.9)$ & $59(8.8)$ \\
\hline Linoleic acid $(N=8614)$ & Low & 2414 (47.9) & $1030(51.3)$ & $562(54.7)$ & $531(62.1)$ \\
\hline a-Linolenic acid $(N=8614)$ & Low & $2491(49.8)$ & $1100(53.8)$ & $603(58.4)$ & $552(63.9)$ \\
\hline Fish oil $(N=8614)$ & Low & $4343(88.7)$ & $1700(88.5)$ & $872(90.6)$ & $764(91.1)$ \\
\hline
\end{tabular}

$R A E$ retinol activity equivalents

*The percentages are weighted

Higher NI score was significantly associated with higher frailty ( $\beta$-coefficient $1.46,95 \% \mathrm{CI} 1.459-1.461)$ and higher mortality risk (HR per $0.1 \mathrm{NI}$ score $1.30,95 \% \mathrm{CI} 1.23-1.36$ ) after adjusting the models for potential covariates. After adjusting the survival analysis additionally for the FI, the HR per $0.1 \mathrm{NI}$ score was 1.19 (95\%CI 1.13-1.26). When analysis was stratified by frailty level, higher NI scores were significantly correlated with higher mortality in individual with FI > 0.1; HR per 0.1 NI score was 1.17 (1.06-1.30) for those with $0.1-0.2 \mathrm{FI}, 1.20(1.08-1.32)$ for those with 0.2-0.3 FI, and $1.27(1.16-1.38)$ for those with FI $>0.3$ (Fig. 4 and Table 14 in Appendix). When we examined the joint effect of nutrition and frailty status on mortality, we found a dose-response relationship (Fig. 5 and Table 15 in Appendix). People with $\mathrm{FI}>0.3$ had a higher mortality risk regardless of nutrition status, whereas having an $\mathrm{FI} \leq 0.1$ was not associated with frailty even for those with $\mathrm{NI}>0.5$. People with $\mathrm{FI}>0.3$ and $\mathrm{NI}>0.5$ had the highest mortality risk (HR 8.17, 95\%CI 5.16-12.94).

\section{Discussion}

This observational study aimed to improve our understanding of the relationship between frailty and nutrition. As expected, we found that the two are related. When we looked at one nutritional parameter at a time (objective 1), the details are complicated: most but not all of the abnormal nutrition-related parameters included in NHANES were related to frailty (19/34 of nutrient intakes, all 5 anthropometric measurements and 21/23 of blood tests). Nevertheless, fewer than half were individually associated with higher mortality risk across frailty levels and their impact differed across levels of frailty (objective 2). A relationship with all-cause mortality was found with one parameter in the $\mathrm{FI} \leq 0.1$ group, 17 parameters in the 0.1-0.2 FI group, 11 parameters in the $0.2-0.3$ FI group, and 16 parameters in the $>0.3 \mathrm{FI}$ group. Only low serum vitamin D significantly increased the mortality risk across all levels of frailty. Even so, when we combined the nutrition-related parameters, including those not significantly associated with mortality, the resulting NI strongly predicted mortality risk, especially among those with higher FI scores (objective 3). In short, overall, the results show that frailty and nutrition are related, and for the most part, unless people are in good health, poor

Table 3 Number of participants with abnormal range of anthropometric measurement by frailty level

\begin{tabular}{|c|c|c|c|c|c|}
\hline \multicolumn{2}{|c|}{ Anthropometric measurements, $N(\%)^{*}$} & \multicolumn{4}{|c|}{ Frailty index score } \\
\hline & & \multirow{2}{*}{$\begin{array}{l}\leq 0.1 \\
N=5119 \\
91(1.9)\end{array}$} & \multirow{2}{*}{$\begin{array}{l}>0.1 \text { to } 0.2 \\
N=2009 \\
22(1.3)\end{array}$} & \multirow{2}{*}{$\begin{array}{l}>0.2 \text { to } 0.3 \\
N=1014 \\
17(1.8)\end{array}$} & \multirow{2}{*}{$\begin{array}{l}>0.3 \\
N=888 \\
10(1.2)\end{array}$} \\
\hline Body mass index $(N=8873)$ & Underweight & & & & \\
\hline & Overweight & $1816(34.5)$ & $702(33.8)$ & $341(31.5)$ & $244(29.3)$ \\
\hline & Obese & $1519(28.6)$ & $735(38.9)$ & $408(44.1)$ & $359(44.2)$ \\
\hline \multirow{2}{*}{$\begin{array}{l}\text { Body weight change in past } 1 \\
\text { year }(N=8852)\end{array}$} & Loss $>10 \%$ & $381(6.8)$ & $194(9.7)$ & $122(10.9)$ & $151(15.6)$ \\
\hline & Gain > 10\% & $872(13.7)$ & $252(12.1)$ & $115(13.3)$ & $104(14.0)$ \\
\hline Waist circumference $(N=8644)$ & High & $3444(67.2)$ & $1603(82.2)$ & $815(85.9)$ & $643(86.1)$ \\
\hline \multirow[t]{2}{*}{ Triceps skinfold $(N=7885)$} & Low & 538 (11.3) & $147(8.1)$ & 84 (8.6) & 76 (10.3) \\
\hline & High & $415(9.3)$ & $184(12.3)$ & $108(15.9)$ & $93(13.5)$ \\
\hline \multirow[t]{2}{*}{ Subscapular skinfold $(N=6884)$} & Low & $428(11.1)$ & $143(9.3)$ & $66(8.4)$ & $62(11.2)$ \\
\hline & High & $281(7.2)$ & $140(9.0)$ & $62(10.0)$ & $45(6.8)$ \\
\hline
\end{tabular}

*The percentages and mean values are weighted 
Table 4 Number of participants with abnormal range of blood levels by frailty level

\begin{tabular}{|c|c|c|c|c|c|}
\hline \multirow[t]{2}{*}{ Blood tests, $N(\%)^{*}$} & & \multicolumn{4}{|c|}{ Frailty index score } \\
\hline & & $\begin{array}{l}\leq 0.1 \\
N=5119\end{array}$ & $\begin{array}{l}>0.1 \text { to } 0.2 \\
N=2009\end{array}$ & $\begin{array}{l}>0.2 \text { to } 0.3 \\
N=1014\end{array}$ & $\begin{array}{l}>0.3 \\
N=888\end{array}$ \\
\hline $\begin{array}{l}\text { Total lymphocyte count } \\
(N=8965)\end{array}$ & Low & $862(17.8)$ & $451(20.9)$ & $272(24.2)$ & $304(34.6)$ \\
\hline \multirow[t]{2}{*}{ Haemoglobin $(N=9017)$} & Low & $304(3.4)$ & $224(7.4)$ & $175(12.6)$ & $216(20.9)$ \\
\hline & High & $40(1.0)$ & $25(1.4)$ & $13(2.1)$ & $9(0.8)$ \\
\hline \multirow{2}{*}{$\begin{array}{l}\text { Mean corpuscular volume } \\
(N=9017)\end{array}$} & Low & $170(2.4)$ & $130(5.3)$ & $30(2.3)$ & $43(4.2)$ \\
\hline & High & $43(0.9)$ & $74(3.7)$ & $56(5.8)$ & $56(6.6)$ \\
\hline Albumin $(N=8916)$ & Low & $308(1.8)$ & $84(1.8)$ & $28(2.2)$ & $68(7.2)$ \\
\hline \multirow[t]{2}{*}{ Vitamin $\mathrm{A}(N=8889)$} & Low & $1(0.0)$ & $2(0.1)$ & $3(0.1)$ & $5(0.6)$ \\
\hline & High & $168(4.4)$ & $148(8.9)$ & $128(13.7)$ & $159(19.0)$ \\
\hline \multirow[t]{2}{*}{ Vitamin $C(N=8886)$} & Low & $264(6.6)$ & $147(7.4)$ & $78(8.3)$ & $82(8.0)$ \\
\hline & High & $77(1.8)$ & $66(3.4)$ & $44(4.6)$ & $36(4.4)$ \\
\hline \multirow[t]{2}{*}{ Vitamin D $(N=8976)$} & Low & $1906(29.4)$ & $740(30.5)$ & $422(35.6)$ & $438(44.6)$ \\
\hline & High & $59(1.5)$ & $9(0.6)$ & $2(0.2)$ & $2(0.3)$ \\
\hline Pyridoxine $(N=8926)$ & Low & $869(15.0)$ & $380(16.5)$ & $206(19.4)$ & $231(25.6)$ \\
\hline Folate, RBC ( $N=8959)$ & Low & $249(4.1)$ & $73(2.7)$ & $40(3.1)$ & $31(3.5)$ \\
\hline Cobalamin $(N=8865)$ & Low & $112(2.0)$ & $50(2.4)$ & $43(4.4)$ & $39(5.3)$ \\
\hline \multirow[t]{2}{*}{ a-carotene $(N=8885)$} & Low & $1045(21.4)$ & $396(20.4)$ & $220(22.5)$ & $241(30.3)$ \\
\hline & High & $562(11.4)$ & $223(11.1)$ & $72(6.1)$ & $54(6.6)$ \\
\hline \multirow[t]{2}{*}{$\beta$-carotene $(N=8501)$} & Low & $908(19.5)$ & $345(20.0)$ & $197(21.9)$ & $189(24.7)$ \\
\hline & High & 565 (11.9) & $277(13.4)$ & $131(11.8)$ & $101(11.0)$ \\
\hline \multirow[t]{2}{*}{$\beta$-cryptoxanthin $(N=8865)$} & Low & $619(15.5)$ & $368(21.4)$ & $247(28.8)$ & $257(35.6)$ \\
\hline & High & $876(12.3)$ & $294(12.1)$ & $122(8.7)$ & $76(7.0)$ \\
\hline \multirow[t]{2}{*}{ Lutein/Zeaxanthin $(N=8889)$} & Low & $1131(26.5)$ & $531(32.0)$ & $307(34.8)$ & $346(46.5)$ \\
\hline & High & $229(3.8)$ & $109(4.8)$ & $46(4.5)$ & $34(3.5)$ \\
\hline \multirow[t]{2}{*}{ Lycopene $(N=8889)$} & Low & $584(10.7)$ & $401(16.3)$ & $317(29.2)$ & $369(40.3)$ \\
\hline & High & $666(14.0)$ & $163(10.0)$ & $55(6.3)$ & $34(5.4)$ \\
\hline \multirow[t]{2}{*}{ Iron, serum $(N=8910)$} & Low & $669(11.6)$ & 309 (13.8) & $145(15.3)$ & $180(20.8)$ \\
\hline & High & $84(1.8)$ & $22(1.1)$ & $10(1.0)$ & $7(1.0)$ \\
\hline \multirow[t]{2}{*}{ Creatinine $(N=8916)$} & Low & $337(3.4)$ & $103(3.7)$ & $40(3.3)$ & $30(4.1)$ \\
\hline & High & $68(1.2)$ & $145(6.0)$ & $166(13.9)$ & $232(24.7)$ \\
\hline Total cholesterol $(N=8950)$ & High & $2380(46.1)$ & $1053(52.6)$ & $445(44.2)$ & $367(43.7)$ \\
\hline Triglyceride $(N=8911)$ & High & $1574(29.1)$ & $734(39.2)$ & $402(42.2)$ & $370(44.1)$ \\
\hline HDL-C $(N=8949)$ & Low & $1453(30.1)$ & $576(30.9)$ & $290(29.8)$ & $312(37.9)$ \\
\hline LDL-C $(N=4161)$ & High & $789(32.7)$ & $318(32.5)$ & $119(24.0)$ & 115 (29.0) \\
\hline \multirow[t]{2}{*}{ Glucose $(N=8916)$} & Low & $141(2.0)$ & $25(1.0)$ & $16(1.4)$ & $20(2.6)$ \\
\hline & High & $814(15.3)$ & $666(31.5)$ & $439(39.7)$ & $423(46.5)$ \\
\hline Homocysteine $(N=8979)$ & High & $21(0.5)$ & $25(1.1)$ & $26(2.1)$ & $46(5.0)$ \\
\hline
\end{tabular}

$H D L-c$ high-density lipoprotein cholesterol, $L D L-c$ low-density lipoprotein cholesterol, $R B C$ red blood cell

*The percentages are weighted

nutritional status increases mortality in a dosedependent fashion, independent of age, sex, marital status, and education.

Several features of these results require additional comment. Regarding the individual items, vitamin D plays an important role in both bone metabolism and non-bony tissue function including skeletal muscles which relate with function in elderly people [58]. Previous observational studies $[59,60]$ including one using the NHANES III data [61] showed that serum 


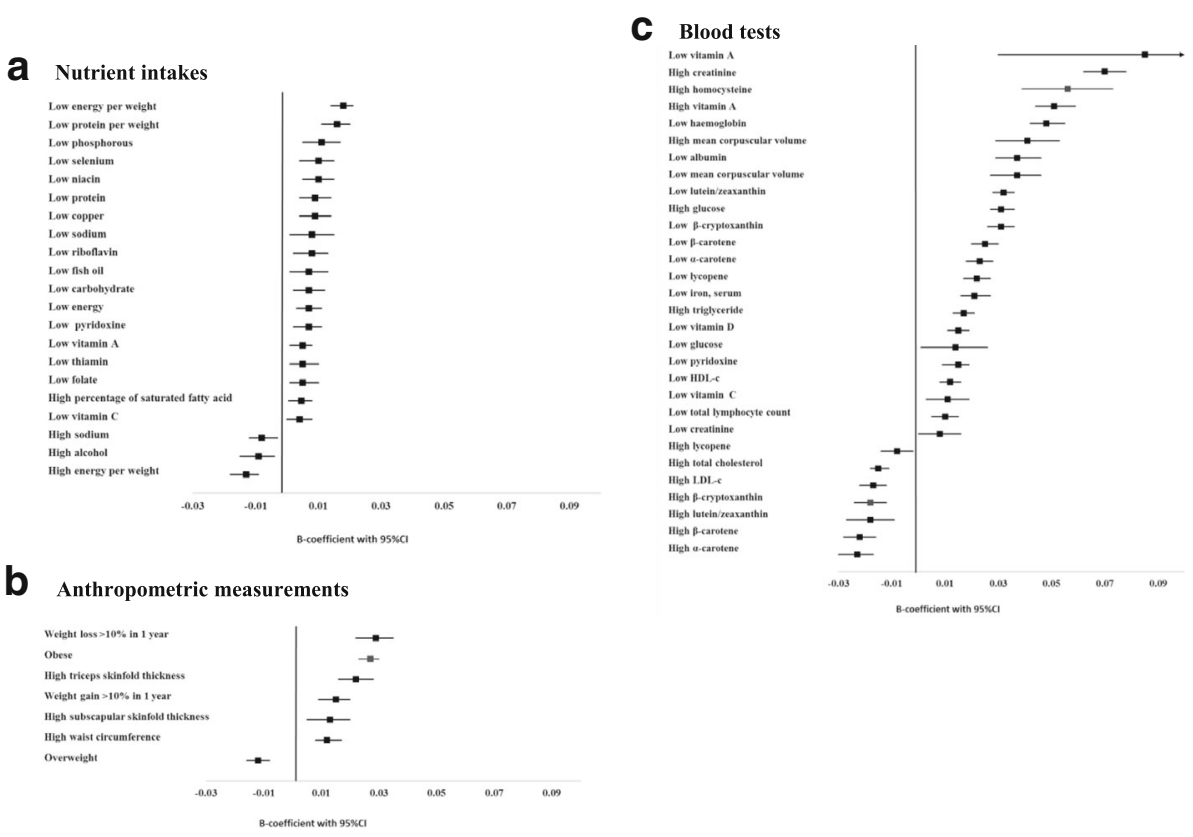

Fig. 1 Association between abnormal nutritional-related parameters and frailty. a Nutrient intakes. b Anthropometric measurements. c Blood tests. HDL-c, high-density lipoprotein cholesterol; LDL-c, low-density lipoprotein cholesterol; MCV, mean corpuscular volume. All analyses were adjusted for age, sex, race, energy intake, educational level, marital status, employment status, smoking, and study cohort except for energy, energy per weight, and dietary fiber per energy which were not adjusted for energy intake

vitamin D levels were correlated with frailty and allcause mortality in older adults. Moreover, a meta-analysis of RCTs [62] reported the benefit of daily vitamin D supplementation on muscle strength and balance in older people. Concerning cognitive function, severe vitamin D deficiency was also correlated with visual memory decline [63]. The current study confirmed the association between low serum vitamin D levels and both frailty levels and mortality risk across levels of frailty, not only in older people but also in younger people.

According to World Health Organization (WHO), the normal range of weight in healthy adults is defined by body mass index (BMI) or Quetelet index between 18.5 and $24.9 \mathrm{~kg} / \mathrm{m}^{2}$ [64]. Even so, human physiology and mortality risk factors change with ageing. A previous meta-analysis [65] showed that a BMI $<23 \mathrm{~kg} / \mathrm{m}^{2}$ was associated with higher mortality risk in older people. BMI alone may not be a good indicator of adiposity in this population and this has been widely demonstrated based on the obesity paradox seen in the older people $[66,67]$. The present study showed that obesity was associated with higher frailty but had no relationship with mortality. In contrast, being underweight increased mortality risk in individuals with $\mathrm{FI}>0.2$ and the mortality risk was lower in people with $\mathrm{FI}>0.3$ who were overweight. It is possible that body composition and weight change may be better predictors in older people than BMI. This study revealed that excessive fat accumulation, high triceps and subscapular skinfold thickness, waist circumference, and change of body weight (loss and gain) more than $10 \%$ in the past year were correlated with higher frailty. Moreover, low triceps skinfold in people with $0.1-0.3 \mathrm{FI}$ and weight loss more than $10 \%$ in the past year in people with $\mathrm{FI}>0.1$ were associated with higher mortality risk.

On the subject of phytochemicals, previous studies $[68,69]$ showed that low serum carotenoids levels were associated with higher frailty. This study also confirmed that low serum alpha-carotene, beta-carotene, beta-cryptoxanthin, lutein/zeaxanthin, and lycopene levels increased the risks of frailty and mortality; high serum levels of these carotenoids were associated with lower frailty levels. The relationship between the amount of dietary carotenoid intakes and their serum levels in older adults should be explored further. Recommending carotenoids-rich fruits and vegetables consumption could be the focus of dietary interventions to improve frailty status.

This study illustrates the virtue of considering deficit accumulation as a means of providing context in age-related disorders. As put pithily in a 2014 Nature commentary, "the problems of old age come as a package" [70]. Deficit accumulation indices can quantify those packages of age-associated problems [71] and 
a Nutrient intakes

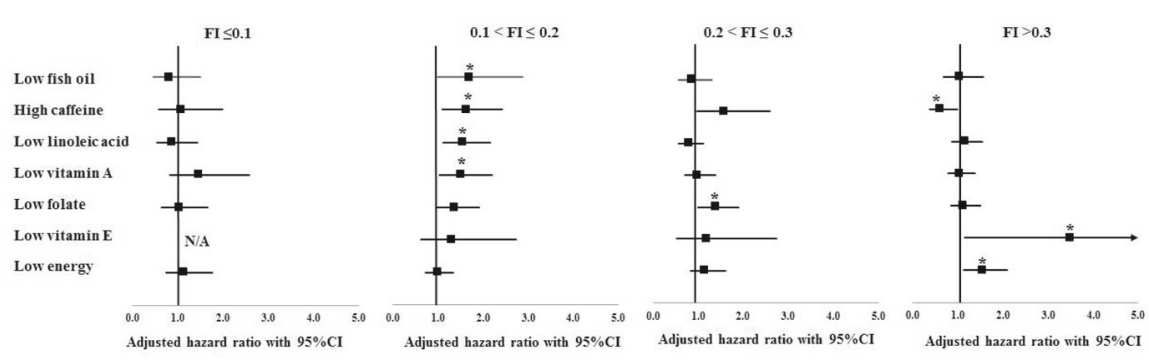

N/A Results are not available due to low sample sizes and mortality rate.

b
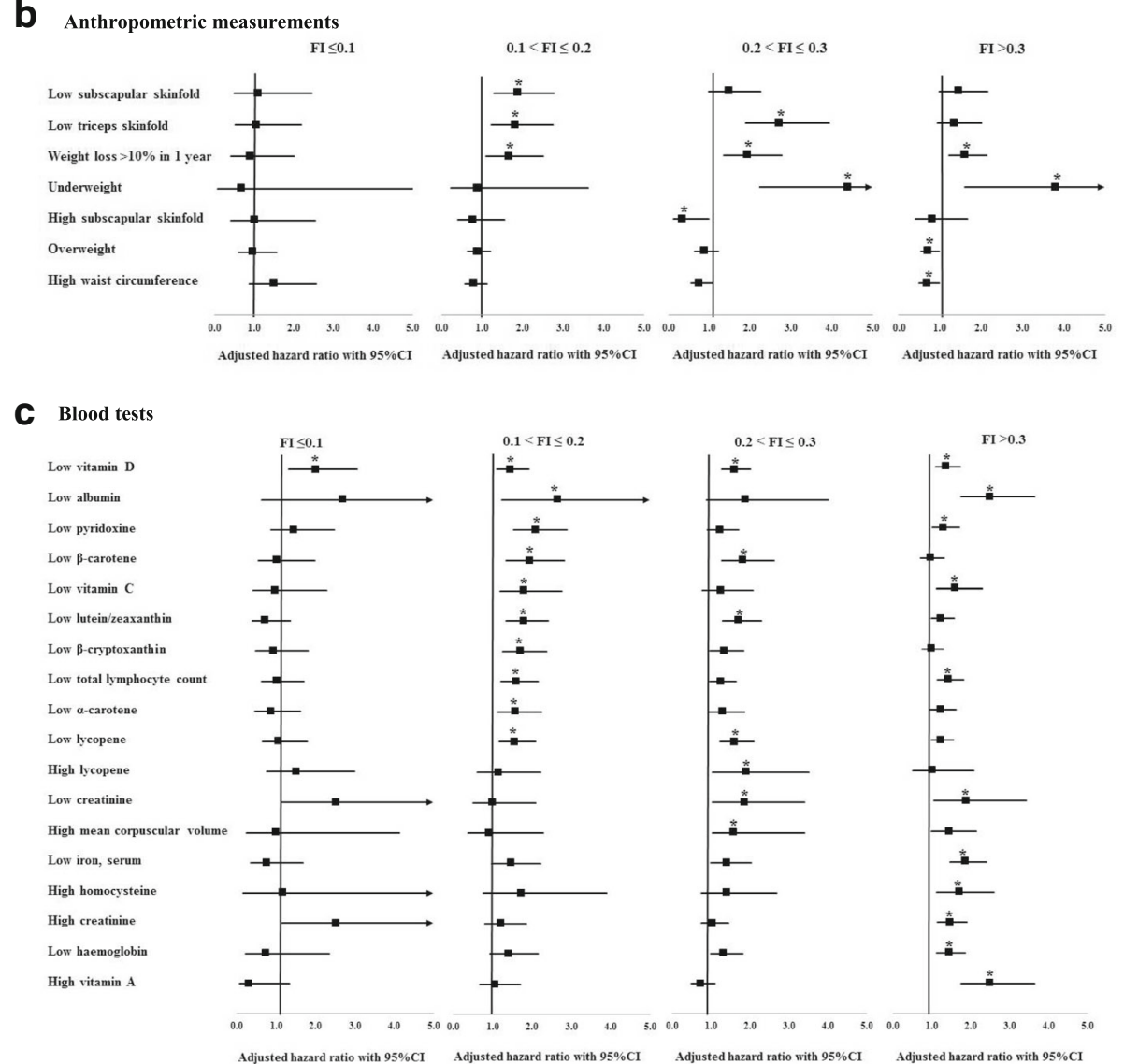

Fig. 2 Association between abnormal nutritional-related parameters and mortality across levels of frailty. a Nutrient intakes. N/A, results are not available due to low sample sizes and mortality rate. b Anthropometric measurements. c Blood tests. Fl, frailty index. All analyses were adjusted for age, sex, race, energy intake, educational level, marital status, employment status, smoking, and study cohort except for energy and energy per weight which were not adjusted for energy intake. ${ }^{*} p$ value $<0.05$

have been used by our group and others in a variety of contexts to quantify the cumulative impact of brain MRI changes [72], social vulnerability measures [73], laboratory measures [74], and ageing biomarkers [75]. An NI, constructed using the deficit accumulation approach, was a stronger prediction of frailty and mortality risk than were single nutritional parameters. This study, similarly to previous studies [76, 77], highlights that the accumulation of small deficits, even those that may not result in clinically detectable problems, corresponds to the ability of the organism to respond and recover from stressors [78]. A recent report noted the benefit to considering 11 nutrition-related parameters in mortality prediction, but did not evaluate frailty [40]. The findings from that work do not contradict our key clinical message: patient management should reflect not just nutritional parameters that cross an illness threshold, but the overall nutritional status. 


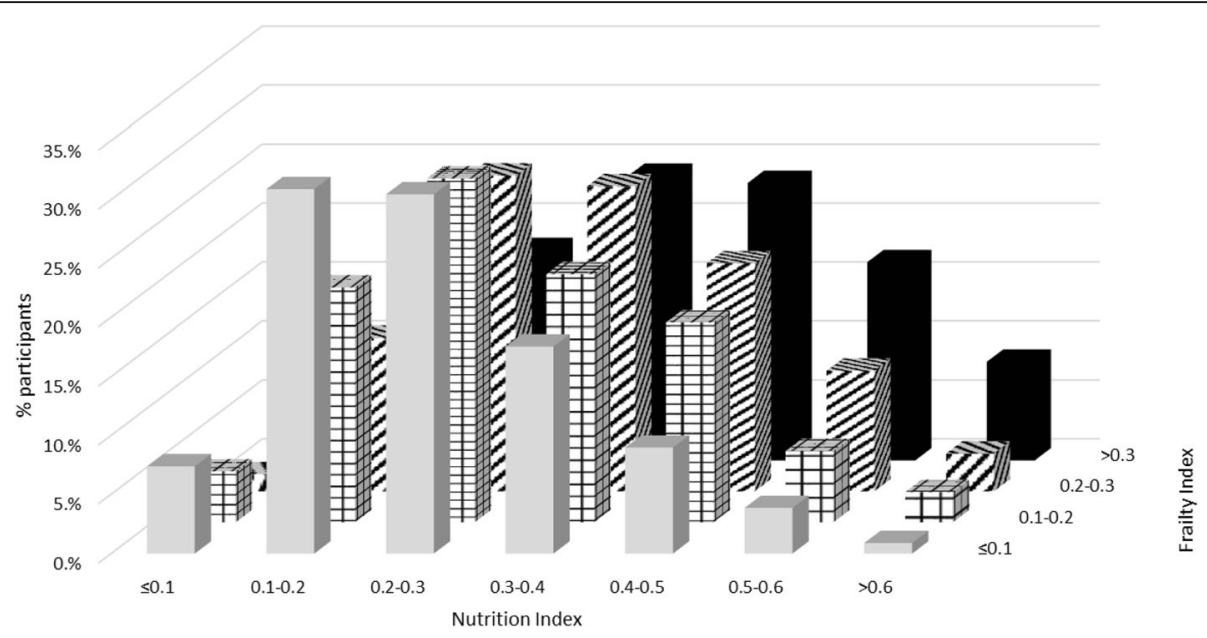

Fig. 3 Percentage of participants in each level of nutritional index score by frailty level. The percentages are weighted

In addition, there appears to be some merit in broader modeling of the nutrition risk as part of age-related deficit accumulation [79]. For example, the doubling time of biomarker deficits appears to be longer than laboratory ones, which in turn are longer than clinical deficits [74, 75, 80], something which appears to reflect their relative connectivity as nodes in a network. How the various types of nutritional deficits fit in this spectrum is of interest, with an initial hypothesis that their variable relationships with mortality might reflect their connectivity (or other network properties). Recent work suggests that information theory might help better analyse factors that influence the health trajectories of individuals [79], offering pragmatic new approaches to studying age-related disease [81].

Here, participants with low energy consumption for their body weight were more likely to be frail. Lower than recommended calorie intake can cause malnutrition; high levels of frailty are common among malnourished people [8]. We also showed a strong association between frailty and body weight changes of more than $10 \%$, both losing and gaining weight in 1 year. Weight loss is a major sign of malnutrition, is included in most of the nutritional screening tools, and is one of the five criteria used in defining the "frailty phenotype" [82]. Weight loss can be caused not only by loss of fat but also by loss of muscle and bony mass [83]. On the other hand, weight gain leads to more fat mass than muscle mass in sedentary young individuals. The fat accumulation itself is associated with many health deficits, especially the metabolic syndrome and metabolic-related diseases. Even so, how the metabolic syndrome and frailty interact in relation to mortality appears to change across the life course [84].

The causes of frailty may be different at each age group. For example, younger people may accumulate deficits due to a chronic condition whereas older people may accumulate deficits even when few comorbidities are present [85]. Similarly, nutritional problems are altered across the lifespan. For example, older people may require more protein and calcium

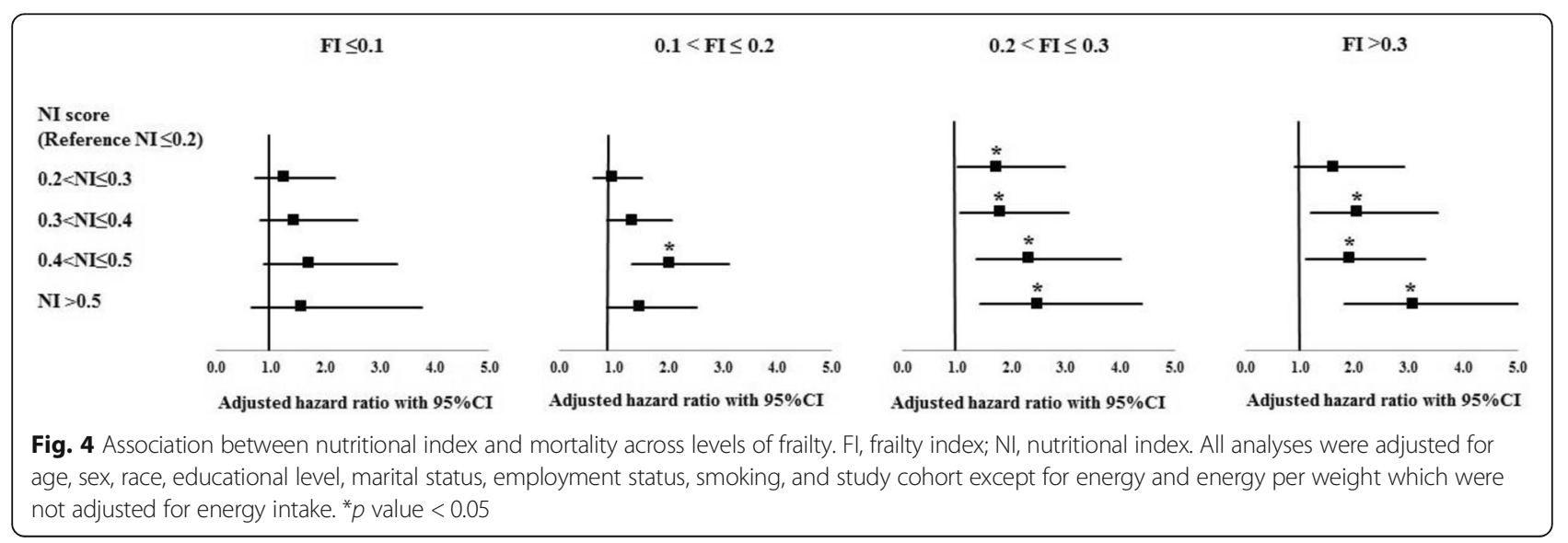




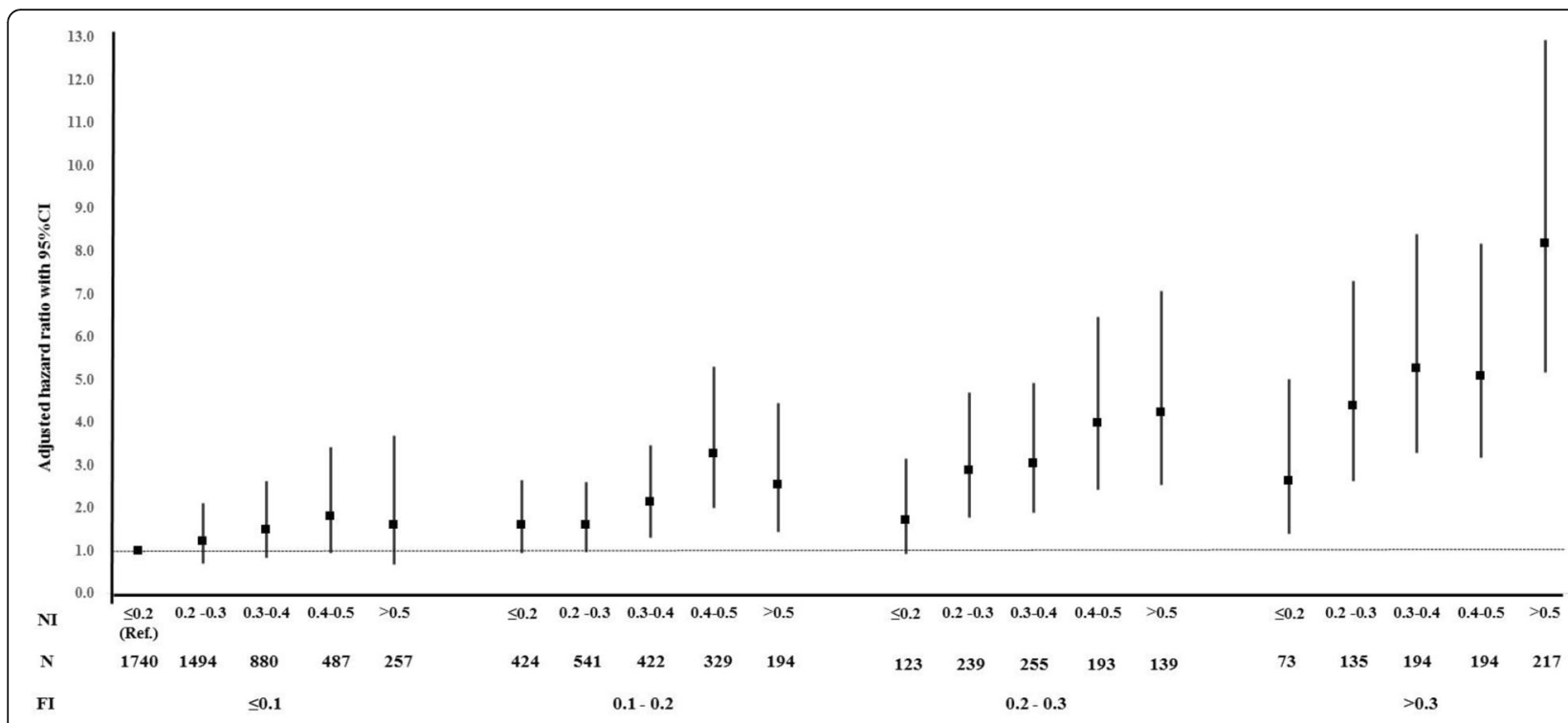

Fig. 5 Combined effect of frailty and nutrition on mortality. Fl, frailty index; NI, nutritional index. All analyses were adjusted for age, sex, race, educational level, marital status, employment status, smoking, and study cohort

intake than do younger people $[45,86]$ whereas the requirement for iron typically declines after the menopause [52]. Here, we recognized this by using cutoff points of normal intake according to the recommendation for each age and gender group. Even so, the effect of abnormal nutrition on frailty can be different in each age group and future interventional studies need to investigate this.

We used publicly available data from NHANES, a large population-based study with a well-controlled and rigorous protocol. We analysed a huge number of nutrition-related parameters. Mortality was extracted from death certificate data and was examined 5-8 years after testing. However, our data must be interpreted with caution: (a) Due to the cross-sectional design, the causal relationship between frailty and nutrition cannot be examined and the duration of exposure to each parameter cannot be explored. For example, here, daily alcohol consumption of more than 2 standard drinks (28 g) in men and 1 standard drink in women (14 g) was associated with lower frailty but was not related with mortality risk. Nevertheless, alcohol consumption more than 3 standard drinks (42 g) per day was not associated with frailty (data not shown). (b) Since dietary data (including alcohol use) were recorded by 24-h recall, day-to-day variation could not be counted, and food intake could be altered along the study period. (c) People who have chronic abnormal serum levels of some nutrients may have experienced temporally normal levels during testing.

The absence of longitudinal data also makes it difficult to discern age from period and cohort effects. Our data do however demonstrate that both frailty and nutritional deficiencies can be detected at all adult ages. Nutritional deficiencies, at least in the aggregate, can also be seen more commonly at higher ages and with frailty, and increase the lethality of frailty. Here, for similar levels of deficit accumulation, at all ages, impaired nutrition reduced survival in people whose FI score were higher than 0.1 .

\section{Conclusions}

This study revealed that most nutritional parameters were related with frailty, but the impact of individual parameters on mortality differed across levels of frailty. Only low vitamin D was associated with higher levels of frailty and higher risk for mortality across all levels of frailty. Weight loss more than $10 \%$ in the past year also increased mortality risk, except in very fit people. Nevertheless, mortality risk was decreased by being overweight, having high waist circumference and subscapular skinfold and consuming more than $400 \mathrm{mg}$ of caffeine daily in people $\mathrm{FI}>0.3$. Even though many nutrition-related parameters were not significantly associated with mortality, we found that in people with FI $>0.1$, they strongly predicted mortality risk when combined in an index. The combined effect of frailty and nutrition deficits had the most impact on mortality risk. Balanced nutritional interventions appear to be reasonable approaches to remediating frailty. Further studies are needed to examine the impact of nutritional interventional studies on frailty levels and to evaluate whether the number of nutritional deficits relates to other health outcomes such as hospitalization, institutionalization, and quality of life. 


\section{Appendix}

Table $\mathbf{5}$ Normal range of parameter

\begin{tabular}{|c|c|c|c|}
\hline \multirow[t]{2}{*}{ Parameter } & \multirow[t]{2}{*}{ Normal range } & \multicolumn{2}{|c|}{ Score in nutritional index } \\
\hline & & 0 & 1 \\
\hline \multicolumn{4}{|l|}{ Nutrient intakes } \\
\hline Energy (kcal/day) & $M \geq 2400, F \geq 1800$ & Normal range & $M<2400, F<1800$ \\
\hline Energy per weight (kcal/kg/day) & $25-35$ & $\geq 25$ & $<25$ \\
\hline Protein (g/day) & $M \geq 56, F \geq 46$ & Normal range & $M<56, F<46$ \\
\hline Protein per weight (g/kg/day) & $\begin{array}{l}<65 \text { years, } \geq 0.8 \\
\geq 65 \text { years, } \geq 1\end{array}$ & Normal range & $\begin{array}{l}<65 \text { years, }<0.8 \\
\geq 65 \text { years, }<1.0\end{array}$ \\
\hline Carbohydrate (g/day) & $\geq 180$ & Normal range & $<180$ \\
\hline Simple sugar (mg/day) & $M<36, F<25$ & -- & -- \\
\hline Dietary fiber (g/1,000 kcal/day) & $>14$ & -- & -- \\
\hline Percentage of fat (\%) & 20-35 & -- & -- \\
\hline Percentage of saturated fat (\%) & $<10$ & Normal range & $\geq 10$ \\
\hline Cholesterol (mg/day) & $<300$ & -- & -- \\
\hline Vitamin A, RAE (mcg/day) & $\begin{array}{l}\text { M 900-3000 } \\
\text { F 700-3000 }\end{array}$ & Normal range & $\begin{array}{l}M<900 \text { or }>3000 \\
F<700 \text { or }>3000\end{array}$ \\
\hline Vitamin C (mg/day) & M 90-2000, F 75-2000 & Normal range & $\begin{array}{l}M<90 \text { or }>2000 \\
F<75 \text { or }>2000\end{array}$ \\
\hline Vitamin E (mg/day) & $15-1000$ & -- & -- \\
\hline Vitamin K (mcg/day) & $M \geq 120, F \geq 90$ & -- & -- \\
\hline Thiamin (mg/day) & $M \geq 1.2, F \geq 1.1$ & Normal range & $M<1.2, F<1.1$ \\
\hline Riboflavin (mg/day) & $M \geq 1.3, F \geq 1.1$ & Normal range & $M<1.3, F<1.1$ \\
\hline Niacin (mg/day) & M 16-35, F 14-35 & Normal range & $\begin{array}{l}M<16 \text { or }>35 \\
F<14 \text { or }>35\end{array}$ \\
\hline Pyridoxine (mg/day) & $\begin{array}{l}\leq 50 \text { years, } 1.3-100 \\
>50 \text { years, M 1.7-100 } \\
>50 \text { years, F 1.5-100 }\end{array}$ & Normal range & $\begin{array}{l}\leq 50 \text { years, }<1.3 \text { or }>100 \\
>50 \text { years, } M<1.7 \text { or }>100 \\
>50 \text { years, } \mathrm{F}<1.5 \text { or }>100\end{array}$ \\
\hline Folate (mcg/day) & $400-1000$ & Normal range & $<400$ or $>1000$ \\
\hline Cobalamin (mcg/day) & $\geq 2.4$ & -- & -- \\
\hline Calcium (mg/day) & $\begin{array}{l}M \leq 70 \text { years, } 1000-2500 \\
M>70 \text { years, } 1200-2500 \\
F \leq 50 \text { years, } 1000-2500 \\
F>50 \text { years, } 1200-2500\end{array}$ & -- & -- \\
\hline Phosphorous (mg/day) & $700-4000$ & Normal range & $<700$ or $>4000$ \\
\hline Magnesium (mg/day) & $M \geq 420, F \geq 320$ & -- & -- \\
\hline Iron (mg/day) & $\begin{array}{l}M 8-45 \\
F \leq 50 \text { years, } 18-45 \\
F>50 \text { years, } 8-45\end{array}$ & -- & -- \\
\hline Zinc (mg/day) & M 11-40, F 8-40 & -- & -- \\
\hline Copper (mg/day) & $0.9-10$ & Normal range & $<0.9$ or $>10$ \\
\hline Sodium (mg/day) & $\begin{array}{l}\leq 50 \text { years, } 1500-2300 \\
>50-70 \text { years, } 1300-2300 \\
>70 \text { years, } 1200-2300\end{array}$ & $\begin{array}{l}\leq 50 \text { years, } \geq 1,500 \\
>50-70 \text { years, } \geq 1300 \\
>70 \text { years, } \geq 1200\end{array}$ & $\begin{array}{l}\leq 50 \text { years, }<1500 \\
>50-70 \text { years, }<1300 \\
>70 \text { years, }<1200\end{array}$ \\
\hline Potassium (mg/day) & $\geq 4700$ & -- & -- \\
\hline Selenium (mcg/day) & $55-400$ & Normal range & $<55$ or $>400$ \\
\hline Caffeine (mg/day) & $\leq 400$ & -- & -- \\
\hline Alcohol (g/day) & $M \leq 28, F \leq 14$ & -- & -- \\
\hline Linoleic acid (g/day) & $\begin{array}{l}\leq 50 \text { years, } M \geq 17, F \geq 12 \\
>50 \text { years, } M \geq 14, F \geq 11\end{array}$ & -- & -- \\
\hline
\end{tabular}


Table 5 Normal range of parameter (Continued)

\begin{tabular}{|c|c|c|c|}
\hline \multirow[t]{2}{*}{ Parameter } & \multirow[t]{2}{*}{ Normal range } & \multicolumn{2}{|c|}{ Score in nutritional index } \\
\hline & & 0 & 1 \\
\hline a-Linolenic acid (g/day) & $M \geq 1.6, F \geq 1.1$ & -- & -- \\
\hline Fish oil $(g / d a y)^{*}$ & $\geq 0.25$ & Normal range & $<0.25$ \\
\hline \multicolumn{4}{|l|}{ Anthropometric measurements } \\
\hline Body mass index $\left(\mathrm{kg} / \mathrm{m}^{2}\right)$ & $18.5-24.9^{* *}$ & $18.5-29.9$ & $<18.5$ or $\geq 30.0$ \\
\hline Body weight change in past 1 year (\%) & $\leq 10$ & Normal range & $>10$ \\
\hline Waist circumference (cm) & $M<94, F<80$ & Normal range & $M \geq 94, F \geq 80$ \\
\hline Triceps skinfold (mm) & M 7.5-24.3, F 14.0-33.7 & Normal range & $\begin{array}{l}M<7.5 \text { or }>24.3 \\
F<14.0 \text { or }>33.7\end{array}$ \\
\hline Subscapular skinfold (mm) & M 10.3-30.5, F 10.3-33.9 & -- & -- \\
\hline \multicolumn{4}{|l|}{ Blood tests } \\
\hline Total lymphocyte count (cells/mm³) & $>1500$ & Normal range & $\leq 1500$ \\
\hline Haemoglobin (g/dL) & M 13.5-18.0, F 12.0-16.0 & Normal range & $\begin{array}{l}M<13.5 \text { or }>18.0 \\
F<12.0 \text { or }>16.0\end{array}$ \\
\hline $\mathrm{MCV}(\mathrm{fL})$ & $80-100$ & Normal range & $<80$ or $>100$ \\
\hline Albumin $(g / L)$ & $35-55$ & Normal range & $<35$ or $>55$ \\
\hline Vitamin A (mcmol/L) & $0.35-3.00$ & Normal range & $<0.35$ or $>3.00$ \\
\hline Vitamin C (mg/dL) & $0.2-2.0$ & Normal range & $<0.2$ or $>2.0$ \\
\hline Vitamin D (ng/mL) & $20-50$ & Normal range & $<20$ or $>50$ \\
\hline Pyridoxine (nmol/L) & $>20$ & Normal range & $\leq 20$ \\
\hline Folate, RBC (ng/mL) & $\geq 140$ & -- & -- \\
\hline Cobalamin (pg/L) & $>200$ & -- & -- \\
\hline a-carotene (mcg/dL) & $1.3-9.2$ & $\geq 1.3$ & $<1.3$ \\
\hline$\beta$-carotene (mcg/dL) & $6.4-35.1$ & $\geq 6.4$ & $<6.4$ \\
\hline$\beta$-cryptoxanthin (mcg/dL) & $4.0-16.4$ & $\geq 4.0$ & $<4.0$ \\
\hline Lutein/Zeaxanthin (mcg/dL) & $11.1-33.0$ & $\geq 11.1$ & $<11.1$ \\
\hline Lycopene (mcg/dL) & $11.9-36.1$ & $\geq 11.9$ & $<11.9$ \\
\hline Iron, serum (mcg/dL) & $50-180$ & Normal range & $<50$ or $>180$ \\
\hline Creatinine (mg/dL) & $\begin{array}{l}\text { M 0.80-1.40, } \\
\text { F 0.56-1.00 }\end{array}$ & Normal range & $\begin{array}{l}M<0.80 \text { or }>1.40 \\
F<0.56 \text { or }>1.00\end{array}$ \\
\hline Total cholesterol (mg/dL) & $<200$ & -- & -- \\
\hline Triglyceride (mg/dL) & $<150$ & Normal range & $\geq 150$ \\
\hline $\mathrm{HDL}-\mathrm{c}(\mathrm{mg} / \mathrm{dL})$ & $M>40, F>50$ & Normal range & $M \leq 40, F \leq 50$ \\
\hline $\mathrm{LDL}-\mathrm{c}(\mathrm{mg} / \mathrm{dL})$ & $<130$ & -- & -- \\
\hline Glucose (mg/dL) & $70-100$ & Normal range & $<70$ or $>100$ \\
\hline Homocysteine (mcmol/L) & $\leq 21.6$ & Normal range & $>21.6$ \\
\hline
\end{tabular}

F female; HDL-c High density lipoprotein cholesterol; $L D L-c$ Low density lipoprotein cholesterol; $M$ male; MCV Mean corpuscular volume; RAE Retinol activity equivalents; $R B C$ red blood cell. -- These variables were excluded from the nutritional index due to high missing data or no relationship with high frailty; * Dietary fish oil is the combination between docosahexaenoic acid (DHA) and eicosapentaenoic acid (EPA) in dietary intake.; ${ }^{* *}<18.5 \mathrm{~kg} / \mathrm{m}^{2}$ (underweight), $25-29.9 \mathrm{~kg} / \mathrm{m}^{2}$ (overweight), $\geq 30 \mathrm{~kg} / \mathrm{m}^{2}$ (obese) 
Table 6 36-item frailty index

\begin{tabular}{|c|c|}
\hline \multicolumn{2}{|l|}{ Self-reported items } \\
\hline 1. Angina/angina pectoris & 14. Difficulty lifting or carrying \\
\hline 2. Heart attack & $\begin{array}{l}\text { 15. Difficulty walking between } \\
\text { rooms on same floor }\end{array}$ \\
\hline 3. Coronary heart disease & $\begin{array}{l}\text { 16. Difficulty standing up from } \\
\text { armless chair }\end{array}$ \\
\hline 4. Stroke & $\begin{array}{l}\text { 17. Difficulty getting in and out of } \\
\text { bed }\end{array}$ \\
\hline 5. Thyroid condition & $\begin{array}{l}\text { 18. Difficulty dressing yourself } \\
\text { difficulty }\end{array}$ \\
\hline 6. Cancer & $\begin{array}{l}\text { 19. Difficulty grasping/holding small } \\
\text { objects }\end{array}$ \\
\hline 7. Arthritis & 20. Difficulty attending social event \\
\hline 8. High blood pressure & 21. Self-reported health \\
\hline 9. Diabetes mellitus & 22. Frequency of healthcare use \\
\hline 10. Weak/failing kidneys & 23. Health compared to 1 year ago \\
\hline $\begin{array}{l}\text { 11. Confusion or inability to } \\
\text { remember things }\end{array}$ & 24. Overnight hospital stays \\
\hline 12. Difficulty managing money & 25. Medications \\
\hline \multicolumn{2}{|l|}{$\begin{array}{l}\text { 13. Difficulty stooping, crouching, } \\
\text { kneeling }\end{array}$} \\
\hline \multicolumn{2}{|l|}{ Laboratory items } \\
\hline 26. Pulse rate (60-99 bpm) & $\begin{array}{l}\text { 32. Red cell distribution width ( } \leq \\
14.6 \%)\end{array}$ \\
\hline $\begin{array}{l}\text { 27. Systolic blood pressure (90- } \\
140 \mathrm{mmHg} \text { ) }\end{array}$ & $\begin{array}{l}\text { 33. Lactate dehydrogenase ( } \leq \\
190 \text { U/L) }\end{array}$ \\
\hline 28. Pulse pressure (30-60 mmHg) & 34. Alkaline phosphatase ( $\leq 115 \mathrm{U} / \mathrm{L})$ \\
\hline $\begin{array}{l}\text { 29. Platelet count SI (150-450 unit } \\
1000 \text { cells/uL) }\end{array}$ & $\begin{array}{l}\text { 35. Uric acid (M: } 240-510, \text { F: } 160- \\
430 \text { umol/L) }\end{array}$ \\
\hline $\begin{array}{l}\text { 30. Blood urea nitrogen (3- } \\
20 \mathrm{mg} / \mathrm{dL} \text { ) }\end{array}$ & 36. Total calcium (2.0-2.5 mmol/L) \\
\hline 31. Bicarbonate ( $\leq 28 \mathrm{mmol} / \mathrm{L})$ & \\
\hline
\end{tabular}

$F$ female, $M$ male 
Table 7 Association between abnormal nutrient intakes and frailty

\begin{tabular}{|c|c|c|c|}
\hline \multirow[t]{2}{*}{ Nutrients } & & \multicolumn{2}{|l|}{ Linear regression analysis } \\
\hline & & $\beta$-coefficient (95\%Cl) & $p$ value \\
\hline Energy & Low & $0.007(0.003,0.011)$ & $0.001^{*}$ \\
\hline \multirow[t]{2}{*}{ Energy per weight } & Low & $0.018(0.014,0.021)$ & $<0.001^{*}$ \\
\hline & High & $-0.013(-0.018,-0.009)$ & $<0.001^{*}$ \\
\hline Protein & Low & $0.009(0.004,0.014)$ & $0.001^{*}$ \\
\hline Protein per weight & Low & $0.016(0.011,0.020)$ & $<0.001^{*}$ \\
\hline Carbohydrate & Low & $0.007(0.002,0.012)$ & $0.004^{*}$ \\
\hline Simple sugar & High & $-0.004(-0.012,0.003)$ & 0.267 \\
\hline Dietary fiber per energy & Low & $0.005(-0.002,0.012)$ & 0.170 \\
\hline \multirow[t]{2}{*}{ Percentage of fat } & Low & $0.003(-0.008,0.014)$ & 0.597 \\
\hline & High & $-0.001(-0.007,0.005)$ & 0.737 \\
\hline $\begin{array}{l}\text { Percentage of saturated } \\
\text { fat }\end{array}$ & High & $0.005(0.001,0.008)$ & $0.018^{*}$ \\
\hline Cholesterol & High & $0.003(-0.002,0.007)$ & 0.213 \\
\hline \multirow[t]{2}{*}{ Vitamin A, RAE } & Low & $0.005(0.001,0.010)$ & $0.027^{*}$ \\
\hline & High & $-0.018(-0.043,0.006)$ & 0.148 \\
\hline \multirow[t]{2}{*}{ Vitamin C } & Low & $0.004(0.001,0.008)$ & $0.027^{*}$ \\
\hline & High & - & \\
\hline Vitamin E & Low & $-0.004(-0.013,0.004)$ & 0.297 \\
\hline Vitamin $\mathrm{K}$ & Low & $0.002(-0.002,0.007)$ & 0.328 \\
\hline Thiamin & Low & $0.005(0.001,0.010)$ & $0.027^{*}$ \\
\hline Riboflavin & Low & $0.008(0.002,0.013)$ & $0.006^{*}$ \\
\hline \multirow[t]{2}{*}{ Niacin } & Low & $0.010(0.005,0.015)$ & $<0.001^{*}$ \\
\hline & High & $0.000(-0.006,0.006)$ & 0.956 \\
\hline Pyridoxine & Low & $0.007(0.002,0.011)$ & $0.003^{*}$ \\
\hline \multirow[t]{2}{*}{ Folate } & Low & $0.005(0.001,0.010)$ & $0.023^{*}$ \\
\hline & High & $0.006(-0.006,0.019)$ & 0.339 \\
\hline Cobalamin & Low & $0.002(-0.002,0.007)$ & 0.354 \\
\hline \multirow[t]{2}{*}{ Calcium } & Low & $-0.003(-0.008,0.002)$ & 0.189 \\
\hline & High & $0.011(-0.003,0.025)$ & 0.134 \\
\hline \multirow[t]{2}{*}{ Phosphorous } & Low & $0.011(0.005,0.017)$ & $<0.001^{*}$ \\
\hline & High & $0.019(-0.010,0.048)$ & 0.201 \\
\hline Magnesium & Low & $0.004(-0.002,0.009)$ & 0.187 \\
\hline \multirow[t]{2}{*}{ Iron } & Low & $0.001(-0.004,0.006)$ & 0.826 \\
\hline & High & $0.012(-0.006,0.030)$ & 0.183 \\
\hline \multirow[t]{2}{*}{ Zinc } & Low & $0.002(-0.003,0.006)$ & 0.499 \\
\hline & High & $0.010(-0.010,0.030)$ & 0.323 \\
\hline \multirow[t]{2}{*}{ Copper } & Low & $0.009(0.004,0.014)$ & $<0.001^{*}$ \\
\hline & High & $-0.014(-0.061,0.032)$ & 0.547 \\
\hline \multirow[t]{2}{*}{ Sodium } & Low & $0.008(0.001,0.015)$ & $0.022^{*}$ \\
\hline & High & $-0.008(-0.012,-0.003)$ & $0.002^{*}$ \\
\hline Potassium & Low & $0.000(-0.008,0.009)$ & 0.971 \\
\hline \multirow[t]{2}{*}{ Selenium } & Low & $0.010(0.004,0.015)$ & $0.001^{*}$ \\
\hline & High & $0.004(-0.032,0.041)$ & 0.809 \\
\hline
\end{tabular}

Table 7 Association between abnormal nutrient intakes and frailty (Continued)

\begin{tabular}{llll}
\hline Nutrients & & \multicolumn{2}{l}{ Linear regression analysis } \\
\cline { 3 - 4 } & & $\beta$-coefficient $(95 \% \mathrm{Cl})$ & $p$ value \\
\hline Caffeine & High & $0.000(-0.007,0.006)$ & 0.911 \\
Alcohol & High & $-0.009(-0.015,-0.004)$ & $0.001^{*}$ \\
Linoleic acid & Low & $0.004(0.000,0.009)$ & 0.060 \\
a-Linolenic acid & Low & $0.004(-0.001,0.008)$ & 0.107 \\
Fish oil & Low & $0.007(0.001,0.013)$ & $0.025^{*}$ \\
\hline
\end{tabular}

RAE retinol activity equivalents

All analyses were adjusted for age, sex, race, energy intake, educational level, marital status, employment status, smoking and study cohort except for energy, energy per weight and dietary fiber per energy which were not adjusted for energy intake

- Results are not available due to low sample sizes and mortality rate, ${ }^{*} p$ value $<0.05$ 
Table 8 Association between abnormal anthropometric measurements and frailty

\begin{tabular}{llll}
\hline Anthropometric measurements & \multicolumn{2}{l}{ Linear regression analysis } \\
\cline { 3 - 4 } & & $\beta$-coefficient $(95 \% \mathrm{Cl})$ & $p$ value \\
\hline Body mass index & Underweight & $-0.008(-0.023,0.007)$ & 0.323 \\
& Overweight & $-0.012(-0.016,-0.008)$ & $<0.001^{*}$ \\
& Obese & $0.027(0.023,0.030)$ & $<0.001^{*}$ \\
Body weight change & Loss $>10 \%$ & $0.029(0.022,0.035)$ & $<0.001^{*}$ \\
in past 1 year & Gain $>10 \%$ & $0.015(0.009,0.020)$ & $<0.001^{*}$ \\
Waist circumference & High & $0.012(0.008,0.017)$ & $<0.001^{*}$ \\
Triceps skinfold & Low & $0.000(-0.006,0.006)$ & 0.989 \\
& High & $0.022(0.016,0.028)$ & $<0.001^{*}$ \\
Subscapular skinfold & Low & $-0.004(-0.011,0.003)$ & 0.224 \\
& High & $0.013(0.005,0.020)$ & $0.001^{*}$
\end{tabular}

All analyses were adjusted for age, sex, race, energy intake, educational level, marital status, employment status, smoking and study cohort, ${ }^{*} p$ value $<0.05$
Table 9 Association between abnormal blood tests and frailty

\begin{tabular}{|c|c|c|c|}
\hline \multirow[t]{2}{*}{ Blood tests } & & \multicolumn{2}{|l|}{ Linear regression analysis } \\
\hline & & $\beta$-coefficient (95\%Cl) & $p$ value \\
\hline Total lymphocyte count & Low & $0.010(0.005,0.015)$ & $<0.001^{*}$ \\
\hline \multirow[t]{2}{*}{ Haemoglobin } & Low & $0.048(0.042,0.055)$ & $<0.001^{*}$ \\
\hline & High & $-0.003(-0.022,0.017)$ & 0.798 \\
\hline \multirow{2}{*}{$\begin{array}{l}\text { Mean corpuscular } \\
\text { volume }\end{array}$} & Low & $0.037(0.027,0.046)$ & $<0.001^{*}$ \\
\hline & High & $0.041(0.029,0.053)$ & $<0.001^{*}$ \\
\hline Albumin & Low & $0.037(0.029,0.046)$ & $<0.001^{*}$ \\
\hline \multirow[t]{2}{*}{ Vitamin A } & Low & $0.085(0.030,0.139)$ & $0.002^{*}$ \\
\hline & High & $0.051(0.044,0.059)$ & $<0.001^{*}$ \\
\hline \multirow[t]{2}{*}{ Vitamin C } & Low & $0.011(0.003,0.019)$ & $0.005^{*}$ \\
\hline & High & $-0.001(-0.013,0.011)$ & 0.845 \\
\hline \multirow[t]{2}{*}{ Vitamin D } & Low & $0.015(0.011,0.019)$ & $<0.001^{*}$ \\
\hline & High & $-0.150(-0.036,0.006)$ & 0.160 \\
\hline Pyridoxine & Low & $0.015(0.010,0.020)$ & $<0.001^{*}$ \\
\hline Folate, RBC & Low & $-0.008(-0.017,0.001)$ & 0.093 \\
\hline Cobalamin & Low & $0.006(-0.005,0.018)$ & 0.287 \\
\hline \multirow[t]{2}{*}{ a-carotene } & Low & $0.023(0.018,0.028)$ & $<0.001^{*}$ \\
\hline & High & $-0.023(-0.030,-0.017)$ & $<0.001^{*}$ \\
\hline \multirow[t]{2}{*}{$\beta$-carotene } & Low & $0.025(0.020,0.030)$ & $<0.001^{*}$ \\
\hline & High & $-0.022(-0.028,-0.016)$ & $<0.001^{*}$ \\
\hline \multirow[t]{2}{*}{$\beta$-cryptoxanthin } & Low & $0.031(0.026,0.036)$ & $<0.001^{*}$ \\
\hline & High & $-0.017(-0.022,-0.012)$ & $<0.001^{*}$ \\
\hline \multirow[t]{2}{*}{ Lutein/Zeaxanthin } & Low & $0.032(0.028,0.036)$ & $<0.001^{*}$ \\
\hline & High & $-0.018(-0.027,-0.009)$ & $<0.001^{*}$ \\
\hline \multirow[t]{2}{*}{ Lycopene } & Low & $0.022(0.017,0.027)$ & $<0.001^{*}$ \\
\hline & High & $-0.008(-0.014,-0.002)$ & $0.014^{*}$ \\
\hline \multirow[t]{2}{*}{ Iron, serum } & Low & $0.021(0.016,0.027)$ & $<0.001^{*}$ \\
\hline & High & $0.001(-0.015,0.016)$ & 0.947 \\
\hline \multirow[t]{2}{*}{ Creatinine } & Low & $0.008(0.000,0.016)$ & $0.048^{*}$ \\
\hline & High & $0.070(0.062,0.078)$ & $<0.001^{*}$ \\
\hline Total cholesterol & High & $-0.015(-0.019,-0.011)$ & $<0.001^{*}$ \\
\hline Triglyceride & High & $0.017(0.013,0.021)$ & $<0.001^{*}$ \\
\hline $\mathrm{HDL}-\mathrm{C}$ & Low & $0.012(0.008,0.016)$ & $<0.001^{*}$ \\
\hline LDL-C & High & $-0.018(-0.024,-0.012)$ & $<0.001^{*}$ \\
\hline \multirow[t]{2}{*}{ Glucose } & Low & $0.014(0.001,0.026)$ & $0.029^{*}$ \\
\hline & High & $0.031(0.027,0.036)$ & $<0.001^{*}$ \\
\hline Homocysteine & High & $0.056(0.039,0.073)$ & $<0.001^{*}$ \\
\hline
\end{tabular}

All analyses were adjusted for age, sex, race, energy intake, educational level, marital status, employment status, smoking and study cohort $H D L-c$ high-density lipoprotein cholesterol, $L D L-c$ low-density lipoprotein cholesterol, $R B C$ red blood cell, ${ }^{*} p$ value $<0.05$ 
Table 10 Associations between abnormal nutrient intakes and mortality across levels of frailty

\begin{tabular}{|c|c|c|c|c|c|c|c|c|c|}
\hline \multirow[t]{3}{*}{ Nutrients } & & \multicolumn{8}{|l|}{ Frailty index score } \\
\hline & & \multirow{2}{*}{$\begin{array}{l}\leq 0.1 \\
\operatorname{HR}(95 \% \mathrm{Cl})\end{array}$} & \multirow[t]{2}{*}{$p$ value } & \multirow{2}{*}{$\begin{array}{l}>0.1 \text { to } 0.2 \\
\text { HR }(95 \% \mathrm{Cl})\end{array}$} & \multirow[t]{2}{*}{$p$ value } & \multirow{2}{*}{$\begin{array}{l}>0.2 \text { to } 0.3 \\
\text { HR }(95 \% \mathrm{Cl})\end{array}$} & \multirow[t]{2}{*}{$p$ value } & \multirow{2}{*}{$\begin{array}{l}>0.3 \\
\operatorname{HR}(95 \% \mathrm{Cl})\end{array}$} & \multirow[t]{2}{*}{$p$ value } \\
\hline & & & & & & & & & \\
\hline Energy & Low & $1.14(0.74,1.77)$ & 0.554 & $1.00(0.73,1.35)$ & 0.976 & $1.16(0.83,1.61)$ & 0.384 & $1.55(1.14,2.10)$ & $0.005^{*}$ \\
\hline \multirow[t]{2}{*}{ Energy per weight } & Low & $1.16(0.72,1.86)$ & 0.547 & $0.87(0.64,1.18)$ & 0.373 & $0.93(0.69,1.25)$ & 0.632 & $1.36(1.00,1.86)$ & 0.052 \\
\hline & High & $0.77(0.40,1.47)$ & 0.427 & $1.11(0.73,1.68)$ & 0.620 & $1.04(0.63,1.73)$ & 0.868 & $1.38(0.85,2.25)$ & 0.195 \\
\hline Protein & Low & $1.09(0.64,1.84)$ & 0.758 & $0.93(0.65,1.32)$ & 0.675 & $0.84(0.61,1.15)$ & 0.266 & $0.93(0.71,1.22)$ & 0.607 \\
\hline Protein per weight & Low & $0.90(0.56,1.45)$ & 0.670 & $1.05(0.76,1.45)$ & 0.765 & $0.80(0.59,1.09)$ & 0.161 & $0.84(0.62,1.12)$ & 0.238 \\
\hline Carbohydrate & Low & $1.25(0.75,2.11)$ & 0.394 & $1.30(0.92,1.83)$ & 0.134 & $1.25(0.90,1.74)$ & 0.178 & $0.88(0.66,1.71)$ & 0.367 \\
\hline Simple sugar & High & $1.02(0.46,2.26)$ & 0.964 & $0.73(0.45,1.17)$ & 0.189 & $0.92(0.57,1.48)$ & 0.720 & $1.15(0.77,1.81)$ & 0.505 \\
\hline Dietary fiber per energy & Low & $0.57(0.32,1.03)$ & 0.064 & $1.42(0.98,2.26)$ & 0.140 & $0.99(0.66,1.48)$ & 0.941 & $0.89(0.62,1.27)$ & 0.510 \\
\hline \multirow[t]{2}{*}{ Percentage of fat } & Low & $1.16(0.31,4.36)$ & 0.822 & $0.62(0.27,1.43)$ & 0.265 & $1.42(0.91,2.21)$ & 0.335 & $0.56(0.31,1.02)$ & 0.990 \\
\hline & High & $1.29(0.61,2.73)$ & 0.509 & $0.68(0.44,1.04)$ & 0.072 & $0.96(0.76,122)$ & 0.121 & $1.049(0.75,1.48)$ & 0.784 \\
\hline $\begin{array}{l}\text { Percentage of saturated } \\
\text { fat }\end{array}$ & High & $0.87(0.58,1.32)$ & 0.523 & $1.27(0.96,1.67)$ & 0.092 & $1.11(0.85,1.44)$ & 0.450 & $0.97(0.78,1.21)$ & 0.800 \\
\hline Cholesterol & High & $1.17(0.74,1.84)$ & 0.502 & $1.03(0.76,1.39)$ & 0.857 & $1.21(0.89,1.66)$ & 0.225 & $1.08(0.84,1.40)$ & 0.552 \\
\hline \multirow[t]{2}{*}{ Vitamin A, RAE } & Low & $1.47(0.83,2.59)$ & 0.184 & $1.51(1.03,2.21)$ & $0.033^{*}$ & $0.99(0.71,1.38)$ & 0.935 & $1.03(0.78,1.37)$ & 0.818 \\
\hline & High & $1.22(0.16,9.41)$ & 0.849 & - & & $2.01(0.72,5.63)$ & 0.182 & - & \\
\hline \multirow[t]{2}{*}{ Vitamin C } & Low & $0.95(0.62,1.45)$ & 0.814 & $1.26(0.94,1.67)$ & 0.121 & $1.19(0.90,1.57)$ & 0.223 & $1.23(0.97,1.56)$ & 0.091 \\
\hline & High & - & & - & & - & & - & \\
\hline Vitamin E & Low & - & & $1.31(0.62,2.73)$ & 0.478 & $1.20(0.53,2.74)$ & 0.658 & $3.49(1.15,11.00)$ & $0.033^{*}$ \\
\hline Vitamin $\mathrm{K}$ & Low & $1.13(0.65,1.97)$ & 0.657 & $1.35(0.92,1.98)$ & 0.121 & $1.06(0.74,1.51)$ & 0.755 & $0.97(0.72,1.31)$ & 0.842 \\
\hline Thiamin & Low & $1.61(0.99,2.60)$ & 0.055 & $1.31(0.95,1.80)$ & 0.095 & $1.17(0.86,1.58)$ & 0.310 & $1.15(0.89,1.48)$ & 0.288 \\
\hline Riboflavin & Low & $0.83(0.45,1.53)$ & 0.548 & $0.93(0.62,1.40)$ & 0.733 & $1.17(0.83,1.65)$ & 0.361 & $1.00(0.75,1.32)$ & 0.992 \\
\hline \multirow[t]{2}{*}{ Niacin } & Low & $1.15(0.70,1.91)$ & 0.581 & $1.16(0.83,1.61)$ & 0.388 & $1.05(0.77,1.43)$ & 0.754 & $0.99(0.76,1.29)$ & 0.945 \\
\hline & High & $0.81(0.39,1.70)$ & 0.580 & $1.10(0.68,1.77)$ & 0.699 & $0.58(0.32,1.05)$ & 0.074 & $1.37(0.89,2.11)$ & 0.148 \\
\hline Pyridoxine & Low & $0.87(0.55,1.39)$ & 0.566 & $0.96(0.71,1.31)$ & 0.815 & $1.26(0.95,1.67)$ & 0.106 & $1.03(0.80,1.32)$ & 0.818 \\
\hline \multirow[t]{2}{*}{ Folate } & Low & $1.04(0.64,1.66)$ & 0.885 & $1.37(0.98,1.91)$ & 0.068 & $1.39(1.01,1.91)$ & $0.042^{*}$ & $1.13(0.84,1.51)$ & 0.413 \\
\hline & High & $1.97(0.59,6.57)$ & 0.269 & $1.35(0.53,3.45)$ & 0.526 & $1.00(0.31,3.21)$ & 0.996 & $0.77(0.19,3.16)$ & 0.714 \\
\hline Cobalamin & Low & $1.10(0.68,1.77)$ & 0.695 & $1.09(0.79,1.49)$ & 0.605 & $1.15(0.86,1.54)$ & 0.351 & $0.94(0.73,1.21)$ & 0.635 \\
\hline \multirow[t]{2}{*}{ Calcium } & Low & $1.20(0.67,2.14)$ & 0.548 & $1.09(0.73,1.62)$ & 0.679 & $1.06(0.74,1.53)$ & 0.747 & $1.05(0.74,1.50)$ & 0.773 \\
\hline & High & $0.74(0.10,5.69)$ & 0.769 & $1.42(0.34,5.99)$ & 0.629 & - & & - & \\
\hline \multirow[t]{2}{*}{ Phosphorous } & Low & $0.67(0.34,1.33)$ & 0.251 & $0.85(0.56,1.29)$ & 0.446 & $1.03(0.71,1.49)$ & 0.888 & $1.14(0.85,1.53)$ & 0.380 \\
\hline & High & - & & - & & - & & - & \\
\hline Magnesium & Low & $0.74(0.41,1.32)$ & 0.307 & $1.49(0.94,2.36)$ & 0.089 & $1.40(0.86,2.28)$ & 0.179 & $1.11(0.73,1.69)$ & 0.634 \\
\hline \multirow[t]{2}{*}{ Iron } & Low & $1.32(0.75,2.31)$ & 0.338 & $1.09(0.75,1.60)$ & 0.650 & $1.17(0.81,1.67)$ & 0.402 & $1.06(0.79,1.42)$ & 0.703 \\
\hline & High & - & & $1.34(0.42,4.30)$ & 0.620 & - & & - & \\
\hline \multirow[t]{2}{*}{ Zinc } & Low & $1.04(0.65,1.67)$ & 0.855 & $1.21(0.89,1.66)$ & 0.228 & $0.90(0.66,1.23)$ & 0.509 & $0.96(0.74,1.25)$ & 0.761 \\
\hline & High & - & & $2.47(0.59,10.41)$ & 0.217 & - & & - & \\
\hline \multirow[t]{2}{*}{ Copper } & Low & $1.24(0.74,2.06)$ & 0.410 & $1.20(0.87,1.68)$ & 0.270 & $1.25(0.92,1.71)$ & 0.154 & $0.79(0.60,1.04)$ & 0.098 \\
\hline & High & $6.35(0.86,46.98)$ & 0.070 & - & & - & & - & \\
\hline \multirow[t]{2}{*}{ Sodium } & Low & $0.79(0.37,1.71)$ & 0.550 & $1.04(0.62,1.72)$ & 0.893 & $0.82(0.47,1.42)$ & 0.475 & $0.96(0.67,1.38)$ & 0.845 \\
\hline & High & $0.64(0.38,1.09)$ & 0.099 & $0.84(0.60,1.17)$ & 0.303 & $1.08(0.79,1.48)$ & 0.609 & $1.13(0.85,1.48)$ & 0.403 \\
\hline Potassium & Low & $0.83(0.33,2.08)$ & 0.695 & $0.86(0.45,1.64)$ & 0.646 & $1.18(0.50,2.80)$ & 0.700 & $1.00(0.43,2.32)$ & 0.996 \\
\hline Selenium & Low & $1.61(0.93,2.77)$ & 0.088 & $1.03(0.70,1.52$ & 0.885 & $1.05(0.76,1.47)$ & 0.757 & $1.06(0.80,1.39)$ & 0.700 \\
\hline & High & - & & - & & - & & - & \\
\hline
\end{tabular}


Table 10 Associations between abnormal nutrient intakes and mortality across levels of frailty (Continued)

\begin{tabular}{|c|c|c|c|c|c|c|c|c|c|}
\hline \multirow[t]{3}{*}{ Nutrients } & & \multicolumn{8}{|c|}{ Frailty index score } \\
\hline & & $\leq 0.1$ & $p$ value & $>0.1$ to 0.2 & $p$ value & $>0.2$ to 0.3 & $p$ value & $>0.3$ & $p$ value \\
\hline & & \multicolumn{2}{|l|}{$\mathrm{HR}(95 \% \mathrm{Cl})$} & \multicolumn{2}{|l|}{$\mathrm{HR}(95 \% \mathrm{Cl})$} & \multicolumn{2}{|l|}{$\mathrm{HR}(95 \% \mathrm{Cl})$} & \multicolumn{2}{|l|}{$\mathrm{HR}(95 \% \mathrm{Cl})$} \\
\hline Caffeine & High & $1.07(0.58,1.98)$ & 0.834 & $1.63(1.09,2.43)$ & $0.016^{*}$ & $1.59(0.97,2.60)$ & 0.064 & $0.61(0.37,0.99)$ & $0.047^{*}$ \\
\hline Alcohol & High & $0.92(0.49,1.74)$ & 0.805 & $1.17(0.81,1.74)$ & 0.386 & $1.18(0.76,1.83)$ & 0.465 & $0.72(0.43,1.22)$ & 0.223 \\
\hline Linoleic acid & Low & $0.88(0.54,1.43)$ & 0.599 & $1.55(1.12,2.16)$ & $0.009^{*}$ & $0.81(0.57,1.13)$ & 0.216 & $1.16(0.87,1.54)$ & 0.312 \\
\hline a-Linolenic acid & Low & $1.12(0.69,1.83)$ & 0.652 & $1.18(0.86,1.63)$ & 0.311 & $0.84(0.60,1.16)$ & 0.279 & $1.21(0.91,1.61)$ & 0.193 \\
\hline Fish oil & Low & $0.82(0.45,1.50)$ & 0.522 & $1.70(1.00,2.88)$ & $0.048^{*}$ & $0.86(0.57,1.30)$ & 0.466 & $1.04(0.69,1.57)$ & 0.850 \\
\hline
\end{tabular}

RAE Retinol activity equivalents

All analyses were adjusted for age, sex, race, energy intake, educational level, marital status, employment status, smoking and study cohort except for energy, energy per weight and dietary fiber per energy which were not adjusted for energy intake

- Results are not available due to low sample sizes and mortality rate, ${ }^{*} p$ value $<0.05$

Table 11 Associations between abnormal anthropometric measurements and mortality across levels of frailty

\begin{tabular}{|c|c|c|c|c|c|c|c|c|c|}
\hline \multicolumn{2}{|c|}{ Anthropometric measurements } & \multicolumn{8}{|c|}{ Frailty index score } \\
\hline & & $\leq 0.1$ & $p$ value & $>0.1$ to 0.2 & $p$ value & $>0.2$ to 0.3 & $p$ value & $>0.3$ & $p$ value \\
\hline & & \multicolumn{2}{|l|}{$\mathrm{HR}(95 \% \mathrm{Cl})$} & \multicolumn{2}{|l|}{$\mathrm{HR}(95 \% \mathrm{Cl})$} & \multicolumn{2}{|l|}{ HR $(95 \% \mathrm{Cl})$} & \multicolumn{2}{|l|}{$\mathrm{HR}(95 \% \mathrm{Cl})$} \\
\hline \multirow[t]{3}{*}{ Body mass index } & Underweight & $0.69(0.09,5.21)$ & 0.723 & $0.88(0.22,3.61)$ & 0.861 & $4.41(2.23,8.74)$ & $<0.001^{*}$ & $3.80(1.60,9.03)$ & $0.002^{*}$ \\
\hline & Overweight & $0.97(0.61,1.57)$ & 0.915 & $0.88(0.64,1.21)$ & 0.421 & $0.90(0.65,1.23)$ & 0.499 & $0.72(0.54,0.98)$ & $0.036^{*}$ \\
\hline & Obese & $0.91(0.52,1.60)$ & 0.742 & $0.82(0.56,1.19)$ & 0.293 & $0.77(0.54,1.11)$ & 0.161 & $0.89(0.66,1.19)$ & 0.424 \\
\hline \multirow{2}{*}{$\begin{array}{l}\text { Body weight change } \\
\text { in past } 1 \text { year }\end{array}$} & Loss $>10 \%$ & $0.91(0.41,2.01)$ & 0.812 & $1.66(1.10,2.50)$ & $0.016^{*}$ & $1.95(1.36,2.79)$ & $<0.001^{*}$ & $1.61(1.21,2.13)$ & $0.001^{*}$ \\
\hline & Gain $>10 \%$ & $1.41(0.66,3.00)$ & 0.380 & $1.66(0.97,2.85)$ & 0.063 & $1.56(0.98,2.47)$ & 0.061 & $1.35(0.91,2.01)$ & 0.139 \\
\hline Waist circumference & High & $1.50(0.88,2.56)$ & 0.135 & $0.80(0.57,1.11)$ & 0.185 & $0.77(0.55,1.09)$ & 0.146 & $0.70(0.50,0.98)$ & $0.037^{*}$ \\
\hline \multirow[t]{2}{*}{ Triceps skinfold } & Low & $1.07(0.53,2.18)$ & 0.842 & $1.83(1.22,2.74)$ & $0.003^{*}$ & $2.73(1.90,3.94)$ & $<0.001^{*}$ & $1.36(0.93,2.00)$ & 0.113 \\
\hline & High & $1.16(0.50,2.71)$ & 0.731 & $1.41(0.85,2.35)$ & 0.184 & $0.74(0.44,1.25)$ & 0.259 & $0.98(0.64,1.51)$ & 0.924 \\
\hline \multirow[t]{2}{*}{ Subscapular skinfold } & Low & $1.10(0.50,2.45)$ & 0.807 & $1.89(1.29,2.77)$ & $0.001^{*}$ & $1.49(0.98,2.26)$ & 0.060 & $1.46(0.99,2.15)$ & 0.058 \\
\hline & High & $1.02(0.41,2.54)$ & 0.970 & $0.78(0.39,1.54)$ & 0.470 & $0.36(0.13,0.98)$ & $0.046^{*}$ & $0.83(0.41,1.66)$ & 0.589 \\
\hline
\end{tabular}

All analyses were adjusted for age, sex, race, energy intake, educational level, marital status, employment status, smoking, and study cohort, ${ }^{*} p$ value $<0.05$ 
Table 12 Associations between abnormal blood tests and mortality across levels of frailty

\begin{tabular}{|c|c|c|c|c|c|c|c|c|c|}
\hline \multirow[t]{3}{*}{ Blood tests } & & \multicolumn{8}{|l|}{ Frailty index score } \\
\hline & & \multirow{2}{*}{$\begin{array}{l}\leq 0.1 \\
H R(95 \% C l)\end{array}$} & \multirow[t]{2}{*}{$p$ value } & \multirow{2}{*}{$\begin{array}{l}>0.1 \text { to } 0.2 \\
\text { HR }(95 \% \mathrm{Cl})\end{array}$} & \multirow[t]{2}{*}{$p$ value } & \multirow{2}{*}{$\begin{array}{l}>0.2 \text { to } 0.3 \\
\text { HR }(95 \% \mathrm{Cl})\end{array}$} & \multirow[t]{2}{*}{$p$ value } & \multirow{2}{*}{$\begin{array}{l}>0.3 \\
\operatorname{HR}(95 \% \mathrm{Cl})\end{array}$} & \multirow[t]{2}{*}{$p$ value } \\
\hline & & & & & & & & & \\
\hline $\begin{array}{l}\text { Total lymphocyte } \\
\text { count }\end{array}$ & Low & $1.03(0.63,1.70)$ & 0.908 & $1.61(1.21,2.15)$ & $0.001^{*}$ & $1.26(0.96,1.65)$ & 0.102 & $1.43(1.14,1.81)$ & $0.002^{*}$ \\
\hline \multirow[t]{2}{*}{ Haemoglobin } & Low & $0.74(0.23,2.36)$ & 0.609 & $1.41(0.93,2.15)$ & 0.110 & $1.33(0.98,1.81)$ & 0.064 & $1.45(1.13,1.86)$ & $0.003^{*}$ \\
\hline & High & $0.70(0.10,5.09)$ & 0.724 & $0.94(0.23,3.84)$ & 0.934 & $3.04(0.72,12.76)$ & 0.129 & - & \\
\hline \multirow{2}{*}{$\begin{array}{l}\text { Mean corpuscular } \\
\text { volume }\end{array}$} & Low & $1.60(0.38,6.64)$ & 0.519 & $0.92(0.37,2.28)$ & 0.863 & $1.72(0.74,3.97)$ & 0.208 & $1.07(0.56,2.04)$ & 0.842 \\
\hline & High & $1.00(0.24,4.14)$ & 0.999 & $1.19(0.69,2.03)$ & 0.533 & $1.58(1.02,2.47)$ & $0.043^{*}$ & $1.45(0.99,2.14)$ & 0.059 \\
\hline Albumin & Low & $2.70(0.63,11.62)$ & 0.183 & $2.66(1.23,5.74)$ & $0.013^{*}$ & $1.88(0.88,4.02)$ & 0.105 & $2.51(1.74,3.64)$ & $<0.001^{*}$ \\
\hline \multirow[t]{2}{*}{ Vitamin A } & Low & - & & - & & - & & - & \\
\hline & High & $0.33(0.08,1.34)$ & 0.121 & $1.06(0.66,1.71)$ & 0.795 & $0.74(0.49,1.10)$ & 0.131 & $1.34(1.02,1.75)$ & $0.035^{*}$ \\
\hline \multirow[t]{2}{*}{ Vitamin C } & Low & $0.98(0.42,2.29)$ & 0.958 & $1.80(1.19,2.75)$ & $0.006^{*}$ & $1.25(0.76,2.07)$ & 0.376 & $1.61(1.13,2.30)$ & $0.009^{*}$ \\
\hline & High & $0.69(0.17,2.83)$ & 0.605 & $0.81(3.94,1.65)$ & 0.554 & $1.02(0.57,1.85)$ & 0.936 & $1.18(0.72,1.93)$ & 0.520 \\
\hline \multirow[t]{2}{*}{ Vitamin D } & Low & $2.01(1.32,3.06)$ & $0.001^{*}$ & $1.45(1.10,1.92)$ & $0.009^{*}$ & $1.62(1.23,2.12)$ & $<0.001^{*}$ & $1.38(1.10,1.73)$ & $0.006^{*}$ \\
\hline & High & - & & - & & - & & - & \\
\hline Pyridoxine & Low & $1.47(0.87,2.48)$ & 0.151 & $2.11(1.54,2.89)$ & $<0.001^{*}$ & $1.24(0.90,1.71)$ & 0.192 & $1.31(1.01,1.70)$ & $0.04^{*}$ \\
\hline Folate, RBC & Low & $0.92(0.33,2.55)$ & 0.877 & $0.93(0.43,2.03)$ & 0.863 & $1.27(0.67,2.41)$ & 0.462 & $0.83(0.39,1.77)$ & 0.630 \\
\hline Cobalamin & Low & $1.34(0.49,3.68)$ & 0.572 & $1.14(0.54,2.43)$ & 0.728 & $0.68(0.34,1.39)$ & 0.294 & $0.97(0.57,1.64)$ & 0.900 \\
\hline \multirow[t]{2}{*}{ a-carotene } & Low & $0.87(0.46,1.63)$ & 0.657 & $1.58(1.12,2.23)$ & $0.009^{*}$ & $1.31(0.92,1.85)$ & 0.131 & $1.23(0.95,1.61)$ & 0.121 \\
\hline & High & $0.78(0.40,1.53)$ & 0.469 & $0.80(0.48,1.32)$ & 0.382 & $0.80(0.48,1.33)$ & 0.383 & $1.00(0.62,1.62)$ & 0.997 \\
\hline \multirow[t]{2}{*}{$\beta$-carotene } & Low & $1.04(0.55,1.99)$ & 0.902 & $1.94(1.33,2.82)$ & $0.001^{*}$ & $1.82(1.26,2.61)$ & $0.001^{*}$ & $0.97(0.71,1.32)$ & 0.854 \\
\hline & High & $0.92(0.51,1.67)$ & 0.784 & $0.91(0.60,1.36)$ & 0.636 & $0.91(0.63,1.31)$ & 0.623 & $0.97(0.69,1.36)$ & 0.846 \\
\hline \multirow[t]{2}{*}{$\beta$-cryptoxanthin } & Low & $0.95(0.49,1.81)$ & 0.867 & $1.71(1.24,2.36)$ & $0.001^{*}$ & $1.34(0.97,1.84)$ & 0.074 & $0.99(0.76,1.29)$ & 0.951 \\
\hline & High & $1.05(0.62,1.80)$ & 0.849 & $0.73(0.45,1.17)$ & 0.194 & $0.98(0.66,1.46)$ & 0.916 & $0.94(0.62,1.42)$ & 0.768 \\
\hline \multirow[t]{2}{*}{ Lutein/Zeaxanthin } & Low & $0.73(0.39,1.36)$ & 0.322 & $1.79(1.33,2.41)$ & $<0.001^{*}$ & $1.72(1.30,2.29)$ & $<0.001^{*}$ & $1.25(0.99,1.58)$ & 0.055 \\
\hline & High & $1.09(0.50,2.40)$ & 0.822 & $0.96(0.51,1.78)$ & 0.891 & $1.20(0.63,2.30)$ & 0.576 & $1.08(0.62,1.88)$ & 0.772 \\
\hline \multirow[t]{2}{*}{ Lycopene } & Low & $1.08(0.65,1.79)$ & 0.774 & $1.56(1.16,2.08)$ & $0.003^{*}$ & $1.60(1.22,2.09)$ & $0.001^{*}$ & $1.24(0.98,1.56)$ & 0.075 \\
\hline & High & $1.52(0.77,3.00)$ & 0.227 & $1.16(0.60,2.22)$ & 0.661 & $1.91(1.04,3.52)$ & $0.037^{*}$ & $1.02(0.50,2.08)$ & 0.965 \\
\hline \multirow[t]{2}{*}{ Iron, serum } & Low & $0.78(0.36,1.69)$ & 0.524 & $1.48(0.98,2.22)$ & 0.061 & $1.41(0.98,2.03)$ & 0.066 & $1.87(1.46,2.41)$ & $<0.001^{*}$ \\
\hline & High & - & & $0.27(0.04,1.90)$ & 0.187 & - & & - & \\
\hline \multirow[t]{2}{*}{ Creatinine } & Low & $2.54(1.15,5.62)$ & 0.021 & $1.01(0.49,2.09)$ & 0.974 & $1.87(1.02,3.41)$ & $0.042^{*}$ & $1.89(1.05,3.42)$ & $0.034^{*}$ \\
\hline & High & $2.46(1.04,5.78)$ & 0.039 & $1.22(0.80,1.86)$ & 0.363 & $1.04(0.75,1.45)$ & 0.798 & $1.48(1.15,1.90)$ & $0.002^{*}$ \\
\hline Total cholesterol & High & $1.05(0.69,1.59)$ & 0.824 & $0.95(0.72,1.26)$ & 0.740 & $0.84(0.64,1.10)$ & 0.200 & $0.92(0.73,1.16)$ & 0.458 \\
\hline Triglyceride & High & $1.33(0.88,2.02)$ & 0.178 & $0.78(0.58,1.06)$ & 0.116 & $0.95(0.72,1.26)$ & 0.728 & $0.95(0.75,1.20)$ & 0.676 \\
\hline $\mathrm{HDL}-\mathrm{C}$ & Low & $1.50(0.67,2.32)$ & 0.071 & $1.08(0.79,1.46)$ & 0.639 & $0.93(0.68,1.28)$ & 0.673 & $1.18(0.94,1.49)$ & 0.158 \\
\hline LDL-C & High & $0.97(0.51,1.87)$ & 0.936 & $0.93(0.61,1.41)$ & 0.729 & $0.60(0.36,0.10)$ & 0.050 & $1.20(0.81,1.77)$ & 0.364 \\
\hline \multirow[t]{2}{*}{ Glucose } & Low & $1.99(0.27,14.73)$ & 0.499 & $1.20(0.38,3.78)$ & 0.758 & $0.44(0.11,1.81)$ & 0.256 & $1.49(0.77,2.87)$ & 0.236 \\
\hline & High & $1.34(0.86,2.09)$ & 0.195 & $1.17(0.89,1.55)$ & 0.263 & $1.09(0.83,1.42)$ & 0.537 & $1.06(0.85,1.34)$ & 0.593 \\
\hline Homocysteine & High & $1.19(0.16,8.69)$ & 0.865 & $1.73(0.76,3.90)$ & 0.190 & $1.41(0.74,2.69)$ & 0.298 & $1.71(1.13,2.60)$ & $0.011^{*}$ \\
\hline
\end{tabular}

$H D L$-c high-density lipoprotein cholesterol, $L D L-c$ low-density lipoprotein cholesterol, $R B C$ red blood cell 
Table 13 Number of participants in each level of nutritional index score by frailty level

\begin{tabular}{|c|c|c|c|c|}
\hline & \multicolumn{4}{|l|}{ Frailty index } \\
\hline & $\begin{array}{l}\leq 0.1 \\
N=4858\end{array}$ & $\begin{array}{l}>0.1 \text { to } 0.2 \\
N=1910\end{array}$ & $\begin{array}{l}>0.2 \text { to } 0.3 \\
N=949\end{array}$ & $\begin{array}{l}>0.3 \\
N=813\end{array}$ \\
\hline \multicolumn{5}{|c|}{ Nutritional index, $N(\%)(N=8530)$} \\
\hline$\leq 0.1(N=393)$ & $305(7.4)$ & $70(4.3)$ & $13(1.5)$ & $5(0.7)$ \\
\hline$>0.1$ to $0.2(N=1967)$ & $1435(30.9)$ & $354(19.9)$ & $110(13.0)$ & $68(8.5)$ \\
\hline$>0.2$ to $0.3(N=2409)$ & $1494(30.5)$ & $541(29.2)$ & $239(26.8)$ & $135(17.8)$ \\
\hline$>0.3$ to $0.4(N=1751)$ & $880(17.6)$ & $422(21.0)$ & $255(25.9)$ & $194(24.2)$ \\
\hline$>0.4$ to $0.5(N=1203)$ & $487(9.0)$ & $329(16.9)$ & $193(19.3)$ & $194(23.5)$ \\
\hline$>0.5$ to $0.6(N=602)$ & $209(3.8)$ & $139(6.0)$ & $104(10.2)$ & $150(16.8)$ \\
\hline$>0.6(N=205)$ & $48(0.9)$ & $55(2.6)$ & $35(3.2)$ & $67(8.4)$ \\
\hline
\end{tabular}

The percentages are weighted

Table 14 Association between nutritional index and mortality across levels of frailty

\begin{tabular}{|c|c|c|c|c|c|c|c|c|}
\hline \multirow[t]{3}{*}{ Nutritional index } & \multicolumn{8}{|c|}{ Frailty index score } \\
\hline & $\leq 0.1$ & $p$ value & $>0.1$ to 0.2 & $p$ value & $>0.2$ to 0.3 & $p$ value & $>0.3$ & $p$ value \\
\hline & HR $(95 \% \mathrm{Cl})$ & & $\mathrm{HR}(95 \% \mathrm{Cl})$ & & $\mathrm{HR}(95 \% \mathrm{Cl})$ & & $\mathrm{HR}(95 \% \mathrm{Cl})$ & \\
\hline Nutritional index score (per 0.1 score) & $1.15(0.98,1.35)$ & 0.082 & $1.17(1.06,1.30)$ & $0.002^{*}$ & $1.20(1.08,1.32)$ & $<0.001^{*}$ & $1.27(1.16,1.38)$ & $<0.001^{*}$ \\
\hline \multicolumn{9}{|l|}{ Nutritional index score in group } \\
\hline$\leq 0.2$ & 1.00 & & 1.00 & & 1.00 & & 1.00 & \\
\hline$>0.2$ to 0.3 & $1.26(0.72,2.18)$ & 0.420 & $0.99(0.64,1.53)$ & 0.958 & $1.73(1.01,2.97)$ & $0.046^{*}$ & $1.63(0.91,2.91)$ & 0.100 \\
\hline$>0.3$ to 0.4 & $1.44(0.80,2.59)$ & 0.219 & $1.35(0.88,2.06)$ & 0.164 & $1.80(1.06,3.05)$ & $0.029^{*}$ & $2.05(1.20,3.52)$ & $0.009^{*}$ \\
\hline$>0.4$ to 0.5 & $1.70(0.88,3.31)$ & 0.117 & $2.04(1.34,3.11)$ & $0.001^{*}$ & $2.34(1.36,4.01)$ & $0.002^{*}$ & $1.92(1.12,3.31)$ & $0.019^{*}$ \\
\hline$>0.5$ & $1.58(0.66,3.76)$ & 0.302 & $1.49(0.89,2.51)$ & 0.130 & $2.49(1.42,4.38)$ & $0.001^{*}$ & $3.09(1.81,5.27)$ & $<0.001^{*}$ \\
\hline$P$ for trend across nutritional index group & & 0.097 & & $0.001^{*}$ & & $0.001^{*}$ & & $<0.001^{*}$ \\
\hline
\end{tabular}

All analyses were adjusted for age, sex, race, educational level, marital status, employment status, smoking, and study cohort, ${ }^{*} p$ value $<0.05$ 
Table 15 Combined effect of frailty and nutrition on mortality

\begin{tabular}{|c|c|c|c|c|}
\hline \multirow{2}{*}{$\begin{array}{l}\text { Frailty index } \\
\text { score }\end{array}$} & \multirow{2}{*}{$\begin{array}{l}\text { Nutrition } \\
\text { index } \\
\text { score }\end{array}$} & \multirow[t]{2}{*}{ N (\%) } & \multicolumn{2}{|c|}{ Cox regression analysis } \\
\hline & & & $\begin{array}{l}\text { Hazard ratio } \\
(95 \% \mathrm{Cl})\end{array}$ & $p$ value \\
\hline \multirow[t]{5}{*}{$\leq 0.1$} & $\leq 0.2$ & $1740(24.5)$ & 1.00 (reference) & \\
\hline & $>0.2$ to 0.3 & $1494(19.5)$ & $1.23(0.71,2.12)$ & 0.468 \\
\hline & $>0.3$ to 0.4 & $880(11.2)$ & $1.48(0.84,2.64)$ & 0.178 \\
\hline & $>0.4$ to 0.5 & $487(5.7)$ & $1.80(0.95,3.42)$ & 0.073 \\
\hline & $>0.5$ & $257(3.0)$ & $1.59(0.68,3.69)$ & 0.281 \\
\hline \multirow[t]{5}{*}{$>0.1$ to 0.2} & $\leq 0.2$ & $424(5.0)$ & $1.59(0.95,2.65)$ & 0.079 \\
\hline & $>0.2$ to 0.3 & $541(6.0)$ & $1.59(0.95,2.65)$ & 0.069 \\
\hline & $>0.3$ to 0.4 & $422(4.3)$ & $2.13(1.31,3.46)$ & $0.002^{*}$ \\
\hline & $>0.4$ to 0.5 & $329(3.5)$ & $3.26(2.01,5.29)$ & $<0.001^{*}$ \\
\hline & $>0.5$ & $194(1.8)$ & $2.53(1.44,4.45)$ & $0.001^{*}$ \\
\hline \multirow[t]{5}{*}{$>0.2$ to 0.3} & $\leq 0.2$ & $123(1.3)$ & $1.70(0.92,3.15)$ & 0.092 \\
\hline & $>0.2$ to 0.3 & $239(2.4)$ & $2.88(1.77,4.68)$ & $<0.001^{*}$ \\
\hline & $>0.3$ to 0.4 & $255(2.3)$ & $3.04(1.88,4.91)$ & $<0.001^{*}$ \\
\hline & $>0.4$ to 0.5 & $193(1.7)$ & $3.97(2.44,6.46)$ & $<0.001^{*}$ \\
\hline & $>0.5$ & $139(1.2)$ & $4.23(2.53,7.08)$ & $<0.001^{*}$ \\
\hline \multirow[t]{5}{*}{$>0.3$} & $\leq 0.2$ & $73(0.6)$ & $2.64(1.39,5.01)$ & $<0.001^{*}$ \\
\hline & $>0.2$ to 0.3 & $135(1.2)$ & $4.38(2.62,7.31)$ & $<0.001^{*}$ \\
\hline & $>0.3$ to 0.4 & $194(1.6)$ & $5.26(3.29,8.39)$ & $<0.001^{*}$ \\
\hline & $>0.4$ to 0.5 & $194(1.6)$ & $5.09(3.16,8.18)$ & $<0.001^{*}$ \\
\hline & $>0.5$ & $217(1.7)$ & $8.17(5.16,12.94)$ & $<0.001^{*}$ \\
\hline
\end{tabular}

The percentages are weighted

All analyses were adjusted for age, sex, race, educational level, marital status, employment status, smoking, and study cohort, ${ }^{*} p$ value $<0.05$

\section{Abbreviations}

BMI: Body mass index; Cl: Confidential interval; Fl: Frailty index; LDL-C: Lowdensity lipoprotein cholesterol; NHANES: National Health and Nutrition Examination Survey; NI: Nutrition index

\section{Acknowledgements}

We are grateful to the Faculty of Medicine Ramathibodi Hospital, Mahidol University, for supporting KJ with a research fellowship to conduct this research; our colleagues in Geriatric Medicine Research, at Dalhousie University \& Nova Scotia Health Authority for their support; all NHANES participants; and the NHANES researchers for making this data publicly available.

\section{Funding}

This study was not funded entirely or partially by an outside source.

\section{Availability of data and materials}

The National Health and Nutrition Examination Survey (NHANES) data are publically available at https://www.cdc.gov/nchs/nhanes/index.htm. The datasets used and/or analysed during the current study are available from the corresponding author on reasonable request.

\section{Authors' contributions}

$\mathrm{KJ}, \mathrm{OT}$, and KR conceived and designed the study, interpreted the data, and co-drafted the manuscript. JB assisted with data analysis and revised the manuscript. LC designed the study and revised the manuscript. All authors reviewed and approved the final manuscript before submission.

\section{Ethics approval and consent to participate}

The protocols of NHANES were approved by the institutional review board of the National Center for Health Statistics, Centers for Disease Control and
Prevention (CDC). Written informed consent was obtained from each participant before participation in this study.

\section{Consent for publication}

Not applicable.

\section{Competing interests}

All authors declare that they have no competing interests.

\section{Publisher's Note}

Springer Nature remains neutral with regard to jurisdictional claims in published maps and institutional affiliations.

\section{Author details}

${ }^{1}$ Chakri Naruebodindra Medical Institute, Faculty of Medicine Ramathibodi Hospital, Mahidol University, Bangkok, Thailand. ${ }^{2}$ Department of Medicine, Dalhousie University, Halifax, Nova Scotia, Canada. ${ }^{3}$ Centre for Health Care of the Elderly, QEll Health Sciences Centre, Nova Scotia Health Authority, Halifax, Nova Scotia, Canada. ${ }^{4}$ MRC Unit for Lifelong Health and Ageing, UCL, London, UK. ${ }^{5}$ Department of Nutrition, Harvard T.H. Chan School of Public Health, Boston, MA, USA. ${ }^{6}$ Division of Geriatric Medicine, Department of Medicine, Dalhousie University, Camp Hill Veterans' Memorial Bldg., 5955 Veterans' Memorial Lane, Halifax, Nova Scotia B3H 2E1, Canada.

Received: 9 July 2018 Accepted: 19 September 2018

Published online: 26 October 2018

\section{References}

1. Lutz W, Sanderson W, Scherbov S. The coming acceleration of global population ageing. Nature. 2008:451(7179):716-9.

2. Ferrucci L, Giallauria F, Guralnik JM. Epidemiology of aging. Radiol Clin N Am. 2008;46(4):643-52 v.

3. Yazdanyar A, Newman AB. The burden of cardiovascular disease in the elderly: morbidity, mortality, and costs. Clin Geriatr Med. 2009;25(4):563-77 vii.

4. Saad MA, Cardoso GP, Martins Wde A, Velarde LG, Cruz Filho RA. Prevalence of metabolic syndrome in elderly and agreement among four diagnostic criteria. Arq Bras Cardiol. 2014;102(3):263-9.

5. Plassman BL, Langa KM, Fisher GG, Heeringa SG, Weir DR, Ofstedal MB, et al. Prevalence of dementia in the United States: the aging, demographics, and memory study. Neuroepidemiology. 2007;29(1-2):125-32.

6. Gheno R, Cepparo JM, Rosca CE, Cotten A. Musculoskeletal disorders in the elderly. J Clin Imaging Sci. 2012;2:39.

7. Hubbard RE, Theou O. Frailty: enhancing the known knowns. Age Ageing 2012;41(5):574-5.

8. Lorenzo-Lopez L, Maseda A, de Labra C, Regueiro-Folgueira L, RodriguezVillamil JL, Millan-Calenti JC. Nutritional determinants of frailty in older adults: a systematic review. BMC Geriatr. 2017:17(1):108.

9. Muscedere J, Waters B, Varambally A, Bagshaw SM, Boyd JG, Maslove D, et al. The impact of frailty on intensive care unit outcomes: a systematic review and meta-analysis. Intensive Care Med. 2017;43(8):1105-22.

10. Walters K, Frost R, Kharicha K, Avgerinou C, Gardner B, Ricciardi F, et al. Home-based health promotion for older people with mild frailty: the HomeHealth intervention development and feasibility RCT. Health Technol Assess. 2017:21(73):1-128.

11. Blodgett JM, Theou O, Howlett SE, Rockwood K. A frailty index from common clinical and laboratory tests predicts increased risk of death across the life course. GeroScience. 2017. https://doi.org/10.1007/s11357-017-99937.

12. Backman K, Joas E, Falk H, Mitnitski A, Rockwood K, Skoog I. Changes in the lethality of frailty over 30 years: evidence from two cohorts of 70-year-olds in Gothenburg Sweden. J Gerontol A Biol Sci Med Sci. 2017;72(7):945-50.

13. Mousa A, Savva GM, Mitnitski A, Rockwood K, Jagger C, Brayne C, et al. Is frailty a stable predictor of mortality across time? Evidence from the Cognitive Function and Ageing Studies. Age Ageing. 2018;47(5):721-7.

14. Constans T, Bacq Y, Brechot JF, Guilmot JL, Choutet P, Lamisse F. Proteinenergy malnutrition in elderly medical patients. J Am Geriatr Soc. 1992;40(3): 263-8.

15. Kaiser MJ, Bauer JM, Ramsch C, Uter W, Guigoz Y, Cederholm T, et al. Frequency of malnutrition in older adults: a multinational perspective using the mini nutritional assessment. J Am Geriatr Soc. 2010;58(9):1734-8. 
16. Kiesswetter E, Pohlhausen S, Uhlig K, Diekmann R, Lesser S, Heseker H, et al. Malnutrition is related to functional impairment in older adults receiving home care. J Nutr Health Aging. 2013;17(4):345-50.

17. Rasheed S, Woods RT. Malnutrition and quality of life in older people: a systematic review and meta-analysis. Ageing Res Rev. 2013;12(2):561-6

18. Correia MI, Waitzberg DL. The impact of malnutrition on morbidity, mortality, length of hospital stay and costs evaluated through a multivariate model analysis. Clin Nutr. 2003;22(3):235-9.

19. Ruengurairoek $T$, Vathesatogkit $P$, Boonhat $H$, Warodomwichit $D$, Thongmuang N, Matchariyakul $D$, et al. The association between processed meat intake and the prevalence of type 2 diabetes in Thais: a crosssectional study from the Electricity Generating Authority of Thailand. Ramathibodi Med J. 2017:40(3):1-10.

20. Ribeiro RV, Hirani V, Senior AM, Gosby AK, Cumming RG, Blyth FM, et al Diet quality and its implications on the cardio-metabolic, physical and general health of older men: the Concord Health and Ageing in Men Project (CHAMP). Br J Nutr. 2017;118(2):130-43.

21. Sao Romao Preto L, Dias Conceicao MDC, Figueiredo TM, Pereira Mata MA Barreira Preto PM, Mateo Aguilar E. Frailty, body composition and nutritional status in non-institutionalised elderly. Enferm Clin. 2017;27(6):339-45.

22. Shlisky J, Bloom DE, Beaudreault AR, Tucker KL, Keller HH, Freund-Levi Y, et al. Nutritional considerations for healthy aging and reduction in age-related chronic disease. Adv Nutr. 2017:8(1):17-26.

23. Theou O, Chapman I, Wijeyaratne L, Piantadosi C, Lange K, Naganathan V, et al. Can an intervention with testosterone and nutritional supplement improve the frailty level of under-nourished older people? J Frailty Aging. 2016:5(4):247-52.

24. Strike SC, Carlisle A, Gibson EL, Dyall SC. A high omega-3 fatty acid multinutrient supplement benefits cognition and mobility in older women: a randomized, double-blind, placebo-controlled pilot study. J Gerontol A Biol Sci Med Sci. 2016;71(2):236-42.

25. Hutchins-Wiese HL, Kleppinger A, Annis K, Liva E, Lammi-Keefe CJ, Durham HA, et al. The impact of supplemental n-3 long chain polyunsaturated fatty acids and dietary antioxidants on physical performance in postmenopausal women. J Nutr Health Aging. 2013;17(1):76-80.

26. van Dijk M, Dijk FJ, Hartog A, van Norren K, Verlaan S, van Helvoort A, et al. Reduced dietary intake of micronutrients with antioxidant properties negatively impacts muscle health in aged mice. J Cachexia Sarcopenia Muscle. 2018;9(1):146-59.

27. Bonnefoy M, Berrut G, Lesourd B, Ferry M, Gilbert T, Guerin O, et al. Frailty and nutrition: searching for evidence. J Nutr Health Aging. 2015; 19(3):250-7

28. Cesari M, Theou O. Frailty: The Broad View. In: Fillit HM, Rockwood K, Young JB. editor. Brocklehurst's Textbook of Geriatric Medicine and Gerontology. 8th ed. Philadelphia: Elsevier, Inc.; 2017. p. 84-7.

29. Aguirre LE, Villareal DT. Physical exercise as therapy for frailty, Nestle Nutrition Institute workshop series, vol. 83; 2015. p. 83-92.

30. Kelaiditi E, van Kan GA, Cesari M. Frailty: role of nutrition and exercise. Curr Opin Clin Nutr Metab Care. 2014;17(1):32-9.

31. Theou O, Stathokostas L, Roland KP, Jakobi JM, Patterson C, Vandervoort AA et al. The effectiveness of exercise interventions for the management of frailty: a systematic review. J Aging Res. 2011;2011:569194.

32. Soysal P, Isik AT, Carvalho AF, Fernandes BS, Solmi M, Schofield P, et al. Oxidative stress and frailty: a systematic review and synthesis of the best evidence. Maturitas. 2017;99:66-72.

33. Ble A, Cherubini A, Volpato S, Bartali B, Walston JD, Windham BG, et al. Lower plasma vitamin $E$ levels are associated with the frailty syndrome: the InCHIANTI study. J Gerontol A Biol Sci Med Sci. 2006;61(3):278-83.

34. Bollwein J, Volkert D, Diekmann R, Kaiser MJ, Uter W, Vidal K, et al. Nutritional status according to the mini nutritional assessment $(M N A(R))$ and frailty in community dwelling older persons: a close relationship. J Nutr Health Aging. 2013;17(4):351-6

35. Shikany JM, Barrett-Connor E, Ensrud KE, Cawthon PM, Lewis CE, Dam TT, et al. Macronutrients, diet quality, and frailty in older men. J Gerontol A Biol Sci Med Sci. 2014;69(6):695-701.

36. Beasley JM, LaCroix AZ, Neuhouser ML, Huang Y, Tinker L, Woods N, et al. Protein intake and incident frailty in the Women's Health Initiative observational study. J Am Geriatr Soc. 2010;58(6):1063-71.

37. Rahi B, Colombet Z, Gonzalez-Colaço Harmand M, Dartigues J-F, Boirie Y, Letenneur $L$, et al. Higher protein but not energy intake is associated with a lower prevalence of frailty among community-dwelling older adults in the French three-city cohort. J Am Med Dir Assoc. 2016;17(7):672.e7-11.

38. Cruz-Jentoft AJ, Kiesswetter E, Drey M, Sieber CC. Nutrition, frailty, and sarcopenia. Aging Clin Exp Res. 2017:29(1):43-8.

39. Theou O, Rockwood K. China's oldest-old-prospects for good health in late life. Lancet. 2017;389(10079):1584-6.

40. Huang YC, Wahlqvist ML, Lo YC, Lin C, Chang HY, Lee MS. A non-invasive modifiable Healthy Ageing Nutrition Index (HANI) predicts longevity in freeliving older Taiwanese. Sci Rep. 2018;8(1):7113.

41. National Center for Health Statistics (NCHS) of the Centers for Disease Control and Prevention (CDC). https://www.cdc.gov/nchs/nhanes/. Cited 28 Dec 2017.

42. Zipf G, Chiappa M, Porter KS, Ostchega Y, Lewis BG, Dostal J. National health and nutrition examination survey: plan and operations, 1999-2010. Vital and health statistics Ser 1, Programs and collection procedures. 2013(56):1-37.

43. Aparicio-Ugarriza R, Palacios G, Alder M, Gonzalez-Gross M. A review of the cut-off points for the diagnosis of vitamin B12 deficiency in the general population. Clin Chem Lab Med. 2015;53(8):1149-59.

44. Ross C, Caballero B, Tucker KL, Cousins RJ. Modern nutrition in health and disease. 11th ed. Baltimore: Lippincott Williams \& Wilkins; 2014.

45. Institute of Medicine. Dietary Reference Intakes for Calcium, Phosphorus, Magnesium, Vitamin D, and Fluoride. Washington, DC: The National Academies Press; 1997. https://doi.org/10.17226/5776.

46. Institute of Medicine. Dietary Reference Intakes for Thiamin, Riboflavin, Niacin, Vitamin B6, Folate, Vitamin B12, Pantothenic Acid, Biotin, and Choline. Washington, DC: The National Academies Press; 1998. https://doi. org/10.17226/6015.

47. Kromhout D, Giltay EJ, Geleijnse JM, Alpha Omega Trial G. n-3 fatty acids and cardiovascular events after myocardial infarction. N Engl J Med. 2010; 363(21):2015-26.

48. Genuth S, Alberti KG, Bennett P, Buse J, Defronzo R, Kahn R, et al. Follow-up report on the diagnosis of diabetes mellitus. Diabetes Care. 2003;26(11):3160-7.

49. National Cholesterol Education Program Expert Panel on Detection E, Treatment of High Blood Cholesterol in A. Third Report of the National Cholesterol Education Program (NCEP) Expert Panel on Detection, Evaluation, and Treatment of High Blood Cholesterol in Adults (Adult Treatment Panel III) final report. Circulation. 2002;106(25):3143-421.

50. Fryar CD, Gu Q, Ogden CL, Flegal KM. Anthropometric Reference Data for Children and Adults: United States, 2011-2014, Vital and health statistics series 3, Analytical Studies, no. 39; 2016. p. 1-46.

51. Alberti KG, Zimmet P, Shaw J, Group IDFETFC. The metabolic syndrome--a new worldwide definition. Lancet. 2005;366(9491):1059-62.

52. Trumbo P, Yates AA, Schlicker $S$, Poos M. Dietary reference intakes: vitamin A, vitamin K, arsenic, boron, chromium, copper, iodine, iron, manganese, molybdenum, nickel, silicon, vanadium, and zinc. J Am Diet Assoc. 2001; 101(3):294-301.

53. U.S. Department of Health and Human Services, U.S. Department of Agriculture. 2015 - 2020 Dietary guidelines for Americans. 8th ed; 2015.

54. Prevention and management of osteoporosis. World Health Organ Tech Rep Ser. 2003;921:1-164, back cover

55. Hosten AO. BUN and Creatinine. In: Walker HK, Hall WD, Hurst JW, editors. Clinical Methods: The History, Physical, and Laboratory Examinations. Boston: Butterworths; 1990. p. 874-8.

56. Theou O, Blodgett JM, Godin J, Rockwood K. Association between sedentary time and mortality across levels of frailty. CMAJ. 2017:189(33):E1056-E64.

57. Mitnitski AB, Mogilner AJ, Rockwood K. Accumulation of deficits as a proxy measure of aging. TheScientificWorldJOURNAL. 2001;1:323-36.

58. Halfon M, Phan O, Teta D. Vitamin D: a review on its effects on muscle strength, the risk of fall, and frailty. Biomed Res Int. 2015;2015:953241.

59. Vogt S, Decke S, de Las Heras Gala T, Linkohr B, Koenig W, Ladwig KH, et al. Prospective association of vitamin D with frailty status and all-cause mortality in older adults: results from the KORA-Age Study. Prev Med. 2015; 73:40-6.

60. Vaes AMM, Brouwer-Brolsma EM, Toussaint N, de Regt M, Tieland M, van Loon LC, et al. The association between 25 -hydroxyvitamin D concentration, physical performance and frailty status in older adults. Eur J Nutr. 2018.

61. Wilhelm-Leen ER, Hall YN, Deboer $H_{H}$, Chertow GM. Vitamin D deficiency and frailty in older Americans. J Intern Med. 2010;268(2):171-80.

62. Muir SW, Montero-Odasso M. Effect of vitamin D supplementation on muscle strength, gait and balance in older adults: a systematic review and meta-analysis. J Am Geriatr Soc. 2011;59(12):2291-300. 
63. Kuzma E, Soni M, Littlejohns TJ, Ranson JM, van Schoor NM, Deeg DJ, et al. Vitamin $\mathrm{D}$ and memory decline: two population-based prospective studies. J Alzheimers Dis. 2016;50(4):1099-108.

64. World Health Organization: Body mass index - BMI. http://www.euro.who. int/en/health-topics/disease-prevention/nutrition/a-healthy-lifestyle/bodymass-index-bmi. Cited 27 Apr 2018.

65. Winter JE, Maclnnis RJ, Wattanapenpaiboon N, Nowson CA. BMI and all-cause mortality in older adults: a meta-analysis. Am J Clin Nutr. 2014;99(4):875-90.

66. Chapman IM. Obesity paradox during aging. Interdiscip Top Gerontol. 2010; 37:20-36.

67. Chang SH, Beason TS, Hunleth JM, Colditz GA. A systematic review of body fat distribution and mortality in older people. Maturitas. 2012;72(3):175-91.

68. Rietman ML, Spijkerman AMW, Wong A, van Steeg H, Burkle A, MorenoVillanueva $\mathrm{M}$, et al. Antioxidants linked with physical, cognitive and psychological frailty: analysis of candidate biomarkers and markers derived from the MARK-AGE study. Mech Ageing Dev. 2018.

69. Semba RD, Bartali B, Zhou J, Blaum C, Ko CW, Fried LP. Low serum micronutrient concentrations predict frailty among older women living in the community. J Gerontol A Biol Sci Med Sci. 2006;61 (6):594-9.

70. Fontana L, Kennedy BK, Longo VD, Seals D, Melov S. Medical research: treat ageing. Nature. 2014;511(7510):405-7.

71. Howlett SE, Rockwood K. Ageing: develop models of frailty. Nature. 2014; 512(7514):253

72. Guo H, Siu W, D'Arcy RC, Black SE, Grajauskas LA, Singh S, et al. MRI assessment of whole-brain structural changes in aging. Clin Interv Aging. 2017:12:1251-70

73. Armstrong JJ, Andrew MK, Mitnitski A, Launer LJ, White LR, Rockwood K. Social vulnerability and survival across levels of frailty in the Honolulu-Asia Aging Study. Age Ageing. 2015;44(4):709-12.

74. Howlett SE, Rockwood MR, Mitnitski A, Rockwood K. Standard laboratory tests to identify older adults at increased risk of death. BMC Med. 2014;12:171.

75. Mitnitski A, Collerton J, Martin-Ruiz C, Jagger C, von Zglinicki T, Rockwood K, et al. Age-related frailty and its association with biological markers of ageing. BMC Med. 2015;13:161

76. Wallace LM, Theou O, Kirkland SA, Rockwood MR, Davidson KW, Shimbo D, et al. Accumulation of non-traditional risk factors for coronary heart disease is associated with incident coronary heart disease hospitalization and death. PLoS One. 2014;9(3):e90475.

77. Brothers TD, Kirkland S, Theou O, Zona S, Malagoli A, Wallace LMK, et al. Predictors of transitions in frailty severity and mortality among people aging with HIV. PLoS One. 2017;12(10):e0185352.

78. Howlett SE, Rockwood K. New horizons in frailty: ageing and the deficitscaling problem. Age Ageing. 2013;42(4):416-23.

79. Rutenberg AD, Mitnitski AB, Farrell SG, Rockwood K. Unifying aging and frailty through complex dynamical networks. Exp Gerontol. 2018;107:126-9.

80. Mitnitski A, Rockwood K. The rate of aging: the rate of deficit accumulation does not change over the adult life span. Biogerontology. 2016;17(1):199-204.

81. Pincus Z. Ageing: A stretch in time. Nature. 2016;530(7588):37-8

82. Fried LP, Tangen CM, Walston J, Newman AB, Hirsch C, Gottdiener J, et al. Frailty in older adults: evidence for a phenotype. J Gerontol A Biol Sci Med Sci. 2001;56(3):M146-56.

83. Huo YR, Suriyaarachchi P, Gomez F, Curcio CL, Boersma D, Gunawardene P, et al. Comprehensive nutritional status in sarco-osteoporotic older fallers. J Nutr Health Aging. 2015;19(4):474-80.

84. Kane AE, Gregson E, Theou O, Rockwood K, Howlett SE. The association between frailty, the metabolic syndrome, and mortality over the lifespan. Geroscience. 2017:39(2):221-9.

85. Theou O, Rockwood MR, Mitnitski A, Rockwood K. Disability and comorbidity in relation to frailty: how much do they overlap? Arch Gerontol Geriatr. 2012;55(2):e1-8.

86. Deutz NE, Bauer JM, Barazzoni R, Biolo G, Boirie Y, Bosy-Westphal A, et al Protein intake and exercise for optimal muscle function with aging: recommendations from the ESPEN Expert Group. Clin Nutr. 2014;33(6):929-36.

Ready to submit your research? Choose BMC and benefit from:

- fast, convenient online submission

- thorough peer review by experienced researchers in your field

- rapid publication on acceptance

- support for research data, including large and complex data types

- gold Open Access which fosters wider collaboration and increased citations

- maximum visibility for your research: over $100 \mathrm{M}$ website views per year

At BMC, research is always in progress.

Learn more biomedcentral.com/submissions 